\title{
From Accounting to Economics: The Role of Aggregate Special Items in Gauging the State of the Economy
}

\begin{abstract}
We propose and find that aggregate special items conveys more information about future real GDP growth than aggregate earnings before special items because the former contains advance news about future economic outcomes. A two-stage rational expectations test reveals that professional forecasters fully understand the information content of aggregate earnings before special items but underestimate that of aggregate special items when revising their GDP forecasts. Using vector autoregressions, we show that aggregate earnings before special items has predictive ability for GDP because, as suggested by previous literature, it acts as a proxy for corporate profits included in national income. In contrast, aggregate special items captures changes in the behavior of economic agents on a timely basis, which in turn have real effects on firms' investment and hiring, as well as consumers' wealth and spending. Consistent with news-driven business cycles, we find that aggregate special items produces synchronized movements across macroeconomic aggregates.
\end{abstract}

Keywords: Aggregate Earnings; Aggregate Special Items; GDP Growth; Asymmetric Timeliness; Rational Expectations; News-driven Business Cycles.

JEL Classifications: E01, E32, E60, M41. 


\section{INTRODUCTION}

Recent macro-accounting research investigating the information content of aggregate accounting data finds a strong association between current aggregate accounting earnings and future economic activity. In this literature, the relation between aggregate accounting earnings and National Income and Product Accounts (NIPA) corporate profits is presumed to be the linking element that explains the association between current aggregate earnings and future GDP growth. This paper revisits the latter association and provides an alternative explanation to the corporate profit link offered in the literature.

Our thesis is that the special item component of aggregate earnings contains significantly more information than aggregate earnings before special items because the former reflects timely news about future economic outcomes. This news channel offers an appealing narrative. When bad news arrives, firms change their expectations about their assets' future cash flows and the expected losses are immediately recognized as special items. These changes in expectations have broad economic effects because, among other things, they affect firms' investment and hiring, consumers' wealth and spending, and ultimately, the economy's real output. In this context, aggregate special items is a powerful predictor of future macroeconomic outcomes because it captures changes in the behavior of economic agents on a timely basis and anticipates the economic consequences of such changes. Importantly, and by construction, our news channel does not overlap with the corporate profit link. This feature of our research design enables us to clearly disentangle between these two alternative explanations.

Pursuing the news explanation more formally, we develop a simple framework that outlines the key relations among economic news, aggregate earnings, and future real GDP growth. With this framework as the basis for our empirical analysis, we start by examining the information content of aggregate earnings before special items and aggregate special items for future real GDP growth. We find that both earnings variables are associated with future real 
GDP growth, however, aggregate special items has a dominant role. For example, in relation to one-quarter-ahead real GDP growth, we find that the marginal contribution of aggregate special items to the model's explanatory power is three times larger than that of aggregate earnings before special items and more economically significant. We also find that the relation between aggregate special items and future real GDP growth is robust to a variety of sensitivity checks such as including controls for different inflation proxies, macroeconomic and financial variables, and GDP growth vintages, as well as using different earnings deflators and alternative time series specifications.

We next revisit the prior finding that forecasts from the Survey of Professional Forecasters (SPF) do not fully incorporate information in aggregate earnings. This evidence is exciting, as aggregate earnings is readily available to professional forecasters when they issue their forecasts. We propose that the forecast inefficiency is likely due to misconceptions that economists have about the recognition of special items in accounting. Anecdotal evidence suggests that economists tend to perceive special items as mere corrections of accounting errors that lack economic content. In fact, our reading of the Bureau of Economic Analysis (BEA) handbook for the calculation of NIPA corporate profits (BEA 2019) confirms that economists at the BEA exclude special items from the measurement of NIPA corporate profits for similar reasons.

Consistent with our thesis, we find that when the SPF macro forecast is included in our regressions, it subsumes the predictive power of aggregate earnings before special items but not that of aggregate special items. To further strengthen our case, we develop a rational expectations test that exploits information in GDP forecast revisions to examine if professional forecasters fully understand the predictive ability of aggregate earnings components. The test results confirm that professional forecasters underreact significantly to aggregate special items but not to aggregate earnings before special items. 
Using macro news as a conditioning variable, we also find that the relation between aggregate special items and future real GDP is sensitive to news. Our results are confirmed when running a parsimonious vector autoregression (VAR) model that incorporates constructs capturing the main elements of an economy. Although frequently used in macroeconomics to address causality concerns, VARs are sparsely used in macro-accounting studies. Based on Orthogonalized Impulse Response Functions (OIRFs), we provide evidence suggesting that aggregate earnings before special items predicts future real GDP growth because it contains information about NIPA corporate profits. However, the predictive power of aggregate earnings before special items disappears when the SPF macro forecast is included in our VAR, suggesting that its information content is fully anticipated. In contrast, aggregate special items captures information about future innovations in real GDP growth unrelated to NIPA corporate profits. We also find that aggregate earnings components are not Granger-caused by real GDP growth and therefore do not simply represent reflections of information in past output growth. Importantly, our results reveal that a shock to aggregate special items (aggregate earnings before special items) explains up to 9 percent (1percent) of the forecast error variance of real GDP growth over a ten-quarter horizon.

To further examine the news view of aggregate special items, we estimate newsaugmented VARs and show that the response of aggregate special items to macro news shocks is immediate, quickly reverting, and mainly attributable to bad news. In contrast, the response of aggregate earnings before special items to macro news shocks is insignificant. Finally, we expand our VAR to include other macro variables in addition to real GDP growth. Consistent with the broad nature of news embedded in aggregate special items, we find that aggregate special items significantly predicts investment, unemployment, disposable income, and consumption. 
We make a number of important contributions to the literature. First, our paper uncovers the role of aggregate special items in explaining the association between aggregate earnings and future macroeconomic outcomes. Different from Hann, Li, and Ogneva (2020) who focus on the labor market, we find, consistent with our news mechanism, that aggregate special items significantly explains common variation in a wide range of macroeconomic outcomes. These findings are particularly relevant since the firm-level evidence on special items suggests they are relatively uninformative in predictive settings.

Second, our earnings decomposition is rooted in theoretically motivated mechanisms that explain the information role of both aggregate earnings components while also taking into account the NIPA estimation procedures. In sharp contrast to Gaertner, Kausar, and Steele (2020) who argue that conservative accruals should better forecast NIPA corporate profits but did not find supporting evidence, we demonstrate that the earnings component unrelated to conservative accruals is the one that contains information about NIPA corporate profits. Understanding the steps taken by the BEA to transform source data into NIPA estimates is important to avoid the inadvertent conclusion that aggregate earnings is not associated with NIPA corporate profits. To the best of our knowledge, our paper is the first to find evidence in support of the corporate profit link. In these regards, our framework provides new insights that help understand how information in aggregate earnings components can map into different aspects of the economy as documented in the literature.

Third, our paper provides a compelling, yet simple, explanation to understand the inefficiency in forecasts of GDP growth with respect to aggregate earnings that has been documented in previous literature. In addition, our rational expectations test, which utilizes information in GDP forecast revisions to infer professional forecasters' expectations of the predictive ability of aggregate earnings, is novel and adds to this literature. 
Fourth, our paper has an implication for economic policy setters. While one of the main uses of NIPA estimates, as set out by the BEA, is to provide the basis for predicting short-term economic activity (BEA handbook Chapter 1), the BEA filters out a relevant source of information in its estimate of corporate profits. Understanding the role of aggregate special items in relation to economic activity may help the BEA incorporate more relevant information.

The remainder of the paper is organized as follows. In Section II, we summarize related literature and outline our framework. Section III describes our research design. In Section IV, we describe the data and variable measurement. We report the main results in Section V with the VAR-related results in Section VI. Finally, Section VII concludes the paper.

\section{RELATED LITERATURE AND FRAMEWORK}

\section{Related Literature}

Our paper is closely related to Konchitchiki and Patatoukas (2014), which demonstrates that aggregate accounting earnings strongly predicts future GDP growth. To justify the association between current aggregate earnings and future GDP growth, existing papers typically assume that aggregate earnings acts as a proxy for NIPA corporate profits, which is a component of GDP. Although the literature has tried to formally investigate this underlying mechanism, no paper has yet found evidence in support of the corporate profit link. In a concurrent paper, Gaertner et al. (2020) argue that conservative accruals in aggregate earnings should better predict the corporate profit component of nominal aggregate output. However, they could not provide any evidence in support of this prediction. Their lack of evidence is not surprising, as NIPA corporate profits are intentionally purged from these accruals. To the contrary, our paper demonstrates that the earnings component unrelated to conservative accruals is the one that predicts the corporate profit component of aggregate output.

Although seemingly intuitive, the corporate profit link faces some challenges. First, there has been a growing difference between aggregate earnings and NIPA corporate profits over 
time, with the correlation between both variables decreasing from 0.89 during the period from 1950-1980 to only 0.35 during the period from 1981-2010 (Dichev 2014). Economists have also recognized this disparity. For example, Nordhaus (2002) notes that the annual growth in aggregate accounting earnings (NIPA corporate profits) was approximately 15 percent (8 percent) during the period from 1992-2000, and that one of the main sources of differences is the exclusion of special items from the measurement of NIPA corporate profits. Second, NIPA corporate profits only account for about 5 percent-10 percent of GDP, which represents a small fraction if one relies on the corporate profit link alone to explain the strong relation between aggregate earnings and future GDP.

Our paper is also related to a recent stream of studies documenting that aggregate earnings is informative about a wide set of macroeconomic outcomes including future investment (Kothari, Lewellen, and Warner 2014; Arif and Lee 2014), future inflation (Shivakumar and Urcan 2017), future money supply and other monetary policy activities (Crawley 2015; Gallo, Hann, and Li 2016; Shivakumar 2007), and future labor market outcomes (Nallareddy and Ogneva 2017; Hann et al. 2020). Nevertheless, the literature does not provide a unified story for why aggregate earnings contains common information about several macro variables.

Finally, our paper is related to a stream of macroeconomics literature that recognizes news as a primary driving force of business cycles. News-driven business cycle theories suggest that business cycle fluctuations are the result of economic agents having incentives to continuously act on news related to future developments about the economy (e.g., Pigou 1927; Beaudry and Portier 2006; Beaudry and Lucke 2010; Barsky and Sims 2011). As stated in the macroeconomics literature, the nature of this news does not need to be topic-specific and the content of the news can be about many diverse subjects, as long as it affects the economy's future prospects (Beaudry and Portier 2014). The broad nature of the economic news driving 
business cycles is consistent with the broad information content in special items, as these items reflect changes in firms' expectations about the future profitability of their assets. ${ }^{1}$

Together with Hann et al. (2020), we take the initiative to examine the differential role of aggregate earnings components for predicting future macroeconomic outcomes. While Hann et al. (2020) focus on the labor market, we examine the role of aggregate earnings components for the overall macroeconomic activity. Although we confirm their findings with respect to the association between aggregate special items and unemployment, we show that the information content of aggregate special items is not limited to the labor market. ${ }^{2}$ We believe that both our news mechanism and their labor market linkage are important transmission channels for accounting information and can be informative for future research.

\section{Framework}

A well-known stylized fact in empirical accounting research is that accounting earnings reflects bad economic news in a timelier manner than good news. ${ }^{3}$ The arrival of bad news changes firms' expectations about their assets' future cash flows and the expected losses are immediately recognized as inventory write-downs, asset impairments, and restructuring charges. These losses are typically referred to as "special items" and given that they are timely in reflecting changes in expectations about the future, they are predominantly forward-looking when compared to other earnings components. ${ }^{4}$ The economic magnitude of the special item component of earnings is far from trivial and could reach up to 90 percent of total assets

\footnotetext{
${ }^{1}$ When discussing our framework, we give some examples of special item recognition linked to changes in expectations about future global economy, trade conditions, economic development associated with Brexit negotiations, and consumer demand associated with the COVID-19 pandemic.

${ }^{2}$ Hann et al. (2020) also support our main results in relation to GDP and show that their labor market mechanism is independent from ours. Gaertner et al. (2020) document another labor market association between negative earnings changes and nominal wages. In an earlier version of our paper, we showed that aggregate special items fully subsumes the predictive ability of negative aggregate earnings changes for nominal output. Gaertner et al. (2020) replicate and confirm our previous findings with respect to the predictive power of aggregate special items. ${ }^{3}$ This property of earnings is typically known as asymmetric timeliness or conditional conservatism (Basu 1997).

${ }^{4}$ We note that the term "special items" is not used in GAAP. However, it has gained popularity in the accounting literature, financial media, and financial databases such as Compustat as a description of "unusual earnings", consistent with the GAAP definition.
} 
(Alciatore, Dee, Easton, and Spear 1998). Therefore, once aggregated across firms, special items can be a powerful predictor for future economic conditions. Figure 1 shows the time series of aggregate special items along with major bad economic events in the US during our sample period. The figure reveals how aggregate special items surged during these economic events. $^{5}$

Casual readings of the financial press also provide anecdotal evidence in favor of aggregate special items being a relevant predictor of future economic conditions. For example, the recent recognition of impairments by big oil producers has been linked to an environment of changing expectations about global economic growth and trade conditions (Financial Times, May 2020). In another recent example, the CEO of Lufthansa acknowledges that the airline will have to take multibillion asset impairments due to the fall in demand caused by COVID19 (Financial Times, April 2020). Finally, the top 15 write-downs for UK companies in 2018 reach $€ 4.23$ billion ( $\$ 4.73$ billion) in response to changing expectations associated with a noBrexit deal (Wall Street Journal, March 2019).

\section{[Insert Figure 1]}

To make our arguments more formal, Figure 2 provides an outline of our framework and highlights the main relations among news, aggregate earnings variables, and future economic growth. Looking at the bottom of Figure 2, our starting point is that accounting earnings tends to recognize bad economic news in a timelier manner than good economic news. In principle, the bad news could be incorporated in different earnings components; however, previous accounting research documents that the recognition of special items is one of the main tools for implementing accounting conservatism (relation 1a). Nevertheless, we allow for the possibility that bad news is also reflected in earnings components other than special items

\footnotetext{
${ }^{5}$ In our setting, the important feature of aggregate special items is that it reflects news on a timely basis. Figure 1 shows that aggregate special items exhibits short-term fluctuations with peaks and troughs. Moreover, troughs are reached relatively quickly when the bad news arrives. The pattern is also consistent with frequent changes in expectations with the arrival of new information.
} 
(relation 1b). Turning to good news, it is unlikely that it will be recognized in aggregate earnings variables on a timely basis. This is because the accounting system requires a higher degree of verification when the news is favorable. Thus, at time $q$, aggregate special items is more likely to reflect advance information about future economic outcomes than other earnings components.

The differences in the measurement of accounting earnings and NIPA corporate profits have some implications for our framework. First, given that the NIPA corporate profit measure excludes special items by construction, the effect of aggregate special items on future output should be more prominent on GDP (or GDI) excluding corporate profits (relation 2b). ${ }^{6}$ This effect is likely not fully anticipated by economists, as it goes beyond the traditional connection with corporate profits. Second, aggregate earnings before special items will be more associated with future aggregate output through the corporate profit link (relation 2d). Given that economists are likely to give more attention to this channel, aggregate earnings before special items is expected to lose its predictive power in specifications where real GDP has been purged from its expected component.

We note that the broad nature of economic news that could be captured in aggregate special items would presumably make it informative about different components of aggregate output and other macroeconomic aggregates. This implies that aggregate special items could also be informative about future NIPA corporate profits. Although excluding special items from the measurement of NIPA corporate profits likely mutes any near-term mechanical association, we allow for this possibility in our framework (relation 2a). In addition, we allow

\footnotetext{
${ }^{6}$ We note that NIPA corporate profits are a component of Gross Domestic Income (GDI), which is theoretically equivalent to GDP. GDI measures economic activity as the sum of all income generated in production, whereas GDP equivalently measures economic activity as the sum of all expenditures in the economy. Therefore, both GDP and GDI should give the same measure of economic activity. NIPA corporate profits cannot be excluded from GDP because GDP contains only expenditure items and not income items. To create a summary measure of economic activity that excludes NIPA corporate profits, we subtract NIPA corporate profits from GDI. Details on the measurement of these variables are provided in the Appendix.
} 
for the possibility that aggregate earnings before special items is associated with components of GDP other than NIPA corporate profits (relation 2c). For example, by considering the expenditure side of output, aggregate earnings before special items likely reflects information about future corporate investments or consumer spending, which in turn could be informative about economy-wide real investment and consumption.

[Insert Figure 2]

\section{RESEARCH DESIGN}

\section{Aggregate Earnings Variables and Future Real GDP Growth}

We start the analysis by examining the predictive ability of our aggregate earnings variables for future real GDP growth using the following time-series regression:

$$
r g d p_{q+n}=\alpha+\beta_{1} e b s p i_{q}+\beta_{2} s p i_{q}+\lambda_{1} r g d p_{q}^{a d v}+\lambda_{2} i n f_{q}+\varepsilon_{q+n}
$$

where $r g d p_{q+n}$ is the final estimate of real GDP growth for quarter $q+n$ and $n=\{1,2,3\}$, $e b s p i_{q}$ is aggregate earnings before special items, $s p i_{q}$ is aggregate special items, $r g d p_{q}^{a d v}$ is the advance (i.e., first) release of real GDP growth, and $i n f_{q}$ is inflation growth.

Aggregate earnings variables are expected to be positively associated with future real GDP growth. Although our focus is on predicting growth in real GDP, we nevertheless control for inflation, as the standard aggregate demand and supply model stipulates that changes in prices result in changes in real output. ${ }^{7}$ Our main inflation variable is based on the Producer Price Index (PPI), as Shivakumar and Urcan (2017) find that aggregate earnings contains significant PPI information. In addition, we consider an alternative inflation proxy based on the Consumer Price Index (CPI). Finally, we include the advance real GDP growth estimate as a control for the autocorrelation in real GDP growth.

\footnotetext{
${ }^{7}$ Previous macro-accounting research documents that accounting earnings contains information about inflation (Shivakumar 2007; Shivakumar and Urcan 2017). Therefore, focusing on real GDP also allows us to distinguish our findings from previous literature.
} 
We estimate all time-series regressions using ordinary least squares (OLS) and report tstatistics based on the Newey and West (1987) heteroscedasticity-and autocorrelationconsistent (HAC) standard errors with a lag length of four. ${ }^{8}$ We report the Shapley values to determine the marginal contribution of each independent variable towards the model's adjusted R-squared (Shapley 1953; Shorrocks 2013). A larger Shapley value indicates a higher marginal contribution of the independent variable in explaining variations in the dependent variable.

\section{Aggregate Earnings Variables, Professional Forecasts, and Rational Expectations}

Previous macro-accounting studies show that aggregate earnings contains information about future GDP growth incremental to the information in professional macro forecasts (Konchitchiki and Patatoukas 2014; Shivakumar and Urcan 2017). We revisit this evidence and examine if the macro forecast inefficiency can be partly attributable to the special item component of aggregate earnings. As we discussed earlier, given that the BEA excludes special items from its measure of corporate profits, professional forecasters are likely to overlook information in aggregate special items when forecasting real GDP.

We test the efficiency of macro forecasts in relation to accounting information using two tests. The first test includes the macro forecast in our GDP predictive regression and examines whether it subsumes information in accounting variables. Accordingly, we estimate the following time-series regression:

$$
\begin{aligned}
r g d p_{q+n}=\alpha & +\beta_{1} e b s p i_{q}+\beta_{2} s p i_{q}+\lambda_{1} r g d p_{q}^{a d v}+\lambda_{2} i n f_{q} \\
& +\lambda_{3} E_{q}\left(r g d p_{q+n}\right)+\varepsilon_{q+n}
\end{aligned}
$$

where $E_{q}\left(r g d p_{q+n}\right)$ is the mean macro forecast of real GDP growth for quarter $q+n$ and $E_{q}($.$) is the mathematical expectation operator conditional on information available at the time$ of forecast. The GDP macro forecast data are from the SPF. A significant $\beta_{i}$ in equation (2)

\footnotetext{
${ }^{8}$ The lag length for the Newey-West correction is based on the rule: lag = number of observations ${ }^{0.25}$ (Greene 2012). The results are not sensitive to the lag length choice. We note that the Newey-West adjustment is most appropriate in a time-series context where observations are not cross-sectionally correlated (Gow, Ormazabal, and Taylor 2010).
} 
suggests that the accounting variable contains information incremental to that of the SPF macro forecast. ${ }^{9}$

The second test is a two-stage rational expectations test in the spirit of Mishkin (1983). Our starting point for this test is to hypothesize that if the professional forecasters are efficient, their GDP forecast revisions should be a function of unanticipated GDP news. From this starting point, we express the revision in macro forecasts as a linear function of our main variables and test for differences between the actual weight aggregate earnings variables carry for predicting future GDP growth, $\beta_{i}$, and the weight professional forecasters give to the earnings variables, $\beta_{i}^{*}$. On this basis, and similar to the typical rational expectations tests in the macroeconomics literature, the efficiency of macro forecasts with respect to earnings variables could be evaluated by comparing differences in these weights, $\beta_{i}-\beta_{i}^{*}$.

Accordingly, we examine if professional forecasters fully impound information in aggregate earnings variables about future real GDP growth when revising their forecasts by jointly estimating the following system of equations:

$$
\begin{aligned}
& r g d p_{q+n}=\alpha+\beta_{1} e b s p i_{q}+\beta_{2} s p i_{q}+\lambda_{1} r g d p_{q}^{a d v}+\lambda_{2} i n f_{q}+e_{q+n} \\
& r e v_{q+n}=r g d p_{q+n}-\alpha^{*}-\beta_{1}^{*} e b s p i_{q}-\beta_{2}^{*} s p i_{q}-\lambda_{1}^{*} r g d p_{q}^{a d v}-\lambda_{2}^{*} i n f_{q}+u_{q+n}
\end{aligned}
$$

where $r e v_{q+n}$ represents the revision in macro forecasts of future real GDP growth measured as the difference between the macro forecast issued after earnings becomes available and the macro forecast that was issued in the previous quarter for the same future GDP variable (i.e., $\left.r e v_{q+n}=E_{q}\left(r g d p_{q+n}\right)-E_{q-1}\left(r g d p_{q+n}\right)\right)$. We use an iterative nonlinear estimation and derive a likelihood ratio statistic (i.e., chi-square) to test whether the observed coefficients from the GDP equation (3a) are equal to the implied coefficients from the macro forecast revision

\footnotetext{
${ }^{9}$ The GDP macro forecast data can be accessed at https://www.philadelphiafed.org/research-and-data/real-timecenter/survey-of-professional-forecasters/.
} 
equation (3b). If professional forecasters do not fully impound the predictable effects of accounting information for future real GDP growth, we expect $\beta_{i} \neq \beta_{i}^{*} .^{10}$

\section{Macro News and the Predictive Ability of Aggregate Earnings Variables}

An implication of our framework is that the predictive ability of aggregate special items - but not that of aggregate earnings before special items - is likely to be sensitive to the arrival of macro news. Referring back to equation (1) and assuming that the time-varying relation between each aggregate earnings variable and future GDP growth can be approximated as a linear function of contemporaneous news, we have:

$$
\beta_{i, q} \approx \beta_{i}^{\prime}+\kappa_{i} \operatorname{news}_{q} \quad i=1,2
$$

where news $q$ is a measure of macro news. Substituting $\beta_{i}$ in equation (1) by its time-varying counterpart, $\beta_{i, q}$, in equation (4) and focusing on one-quarter-ahead GDP growth, we obtain:

$$
\begin{aligned}
r g d p_{q+1}=\alpha+\left(\hat{\beta_{1}}\right. & \left.+\kappa_{1} \operatorname{news}_{q}\right) \operatorname{ebspi}_{q}+\left(\grave{\beta_{2}}+\kappa_{2} \operatorname{news}_{q}\right) \operatorname{spi}_{q}+\lambda_{1} r g d p_{q}^{a d v} \\
& +\lambda_{2} i n f_{q}+\varepsilon_{q+1}
\end{aligned}
$$

Re-arranging equation (5) in line with equation (1), it is straightforward to show that:

$$
\begin{gathered}
r g d p_{q+1}=\alpha+\hat{\beta_{1} e b s p i_{q}}+\grave{\beta_{2} s p i_{q}+\lambda_{1} r g d p_{q}^{a d v}+\lambda_{2} i n f_{q}+\kappa_{1} e b s p i_{q} \times n e w s_{q}} \\
+\kappa_{2} \operatorname{spi}_{q} \times n e w s_{q}+\varepsilon_{q+1}
\end{gathered}
$$

Equation (6) indicates that $\beta_{i}$ in equation (1) can be time-varying, with news $q$ acting as a conditioning variable. It follows that, if our news hypotheses in relation to aggregate earnings variables hold empirically, $\kappa_{2}\left(\kappa_{1}\right)$ is expected to be significant (insignificant).

We measure $n e w s_{q}$ using a macro news index from the Michigan Survey of Consumers. Survey participants answer a question asking them about recent "news heard" concerning the macroeconomy, and their responses are tabulated into favorable and unfavorable news

\footnotetext{
${ }^{10}$ In accounting research, a rational expectations test is traditionally used to examine if investors fully understand the implications of current earnings variables for future earnings (Sloan 1996). Our rational expectations test is another application of Mishkin (1983), where we examine if professional forecasters fully understand the implications of current earnings information for future real GDP growth. Abel and Mishkin (1983) note that rational expectations tests are compatible with different settings in macroeconomics.
} 
indexes. ${ }^{11}$ news $q$ is a relative score measured as the unfavorable news index minus the favorable news index plus 100. To further examine whether the hypothesized time variation in $\beta_{i}$ is mainly attributable to bad or good news, we also estimate equation (6) when news $q$ is replaced with badnews $q$ based on the unfavorable news index or goodnews $s_{q}$ based on the favorable news index.

\section{Aggregate Earnings Variables and the Macroeconomy: Vector Autoregression Analysis}

We follow the literature in designing our baseline models. Most macro-accounting studies use relatively simple time-series models to analyze the predictive ability of aggregate earnings for future economic outcomes. ${ }^{12}$ Among the potential problems that could arise due to the use of simplified models is the complex interactions among macro variables that could interfere with the way we interpret results from the OLS regressions. To mitigate this potential concern, we conduct VAR analyses and use OIRFs for inferences. Commonly used in the macroeconomics literature, the OIRFs allow us to shock one variable in the system and examine the multi-horizon effects of the variable's shock on other variables while holding everything else constant.

Our VAR is parsimonious but includes the main elements of an economy. Specifically, the VAR features macro variables that represent the targets of the monetary policy (i.e., inflation and unemployment), the main monetary policy tool (i.e., interest rate), and the role of expectations (i.e., professional forecasts), in addition to aggregate earnings variables and our target macro variable (i.e., real GDP growth). Our VAR takes the following form:

$$
Y_{q+n}=A+B Y_{q}+\varepsilon_{q+n}
$$

\footnotetext{
11 The wording of the question is "During the last few months, have you heard of any favorable or unfavorable change in business conditions? and "What did you hear?". The relative news score can add to more than 100\% due to multiple mentions.

${ }^{12}$ A notable exception is Shivakumar and Urcan (2017), who derive their main results about the relation between aggregate earnings and inflation using VAR analysis.
} 
where $Y_{q}=\left(\right.$ inf $_{q}$, unem $_{q}$, int $\left._{q}, E_{q}\left(r g d p_{q+1}\right), s p i_{q}, \operatorname{ebspi}_{q}, r g d p_{q}\right)$, unem $_{q}$ is the rate of unemployment and $i n t_{q}$ is the interest rate. Across our study, we adapt our VAR in equation (7) to accommodate decompositions or alternative proxies of our main constructs.

We estimate one-lag VARs as suggested by different lag-order selection statistics including the final prediction error, Schwarz's Bayesian information criterion, and the Hannan and Quinn information criterion. The OIRFs are estimated by diagonalizing the contemporaneous variance-covariance matrix of regression residuals using the Cholesky decomposition (Stock and Watson 2001).

\section{SAMPLE AND DESCRIPTIVE STATISTICS}

We collect quarterly accounting data from Compustat, stock price data from CRSP, and macroeconomic data from different sources, details of which are provided in the Appendix. For each firm-quarter observation, we measure earnings before special items as the year-over-year change in scaled quarterly earnings before extraordinary items (Compustat item ibq) less special items (Compustat item spiq). We measure special items as scaled quarterly special items. ${ }^{13}$ We scale firm-level earnings variables by sales. Finally, we aggregate firm-level accounting data using value-weighted cross-sectional averages with weights based on the market value of equity as of the beginning of the quarter.

We obtain quarterly real GDP growth, $r g d p$, from the Real-Time Data Research Center of the Federal Reserve Bank of Philadelphia as of October 2015, and macro forecasts of future real GDP growth from the SPF. To measure NIPA corporate profit growth, $r c p$, we collect

\footnotetext{
${ }^{13}$ One could think of special items as being a component of earnings and therefore it might seem natural to use a change specification similar to that of earnings before special items. However, the special item component of earnings is transitory by definition and already captures changes in circumstances. Therefore, a level specification is more economically meaningful (e.g., Easton and Harris 1991; Ali and Zarowin 1992; Francis, Hanna, and Vincent 1996; Elliot and Hanna 1996). Consistently, in untabulated results we find using a level specification that aggregate earnings before special items is persistent for several lags whereas aggregate special items is not. These empirical findings provide additional support for a change specification for aggregate earnings before special items and a level specification for aggregate special items. Nevertheless, in robustness tests we show that our inferences with respect to aggregate special items are not affected by alternative time-series specifications.
} 
quarterly nominal corporate profits from Line 17 of the NIPA Table 1.7.5. To measure Gross Domestic Income (GDI) growth excluding corporate profits, $r$ gdiecp, we collect quarterly nominal GDI from Line 26 of the NIPA Table 1.7.5 and then subtract nominal corporate profits. To convert nominal corporate profits and GDI excluding corporate profits into real values, we use the GDP deflator from Line 1 of the NIPA Table 1.1.9; and to calculate growth rates, we use year-over-year percentage changes. For macro news, news, we use survey data from the Michigan Survey of Consumers summarizing responses to a question about recent macro news heard following Barsky and Sims (2012). The data are from Table 23 of the Michigan Survey.

To align accounting data with macroeconomic data, we follow previous research and restrict our sample to firms with fiscal quarters ending in March, June, September, and December, and those with earnings announcement dates no later than 45 days after the end of the fiscal quarter. ${ }^{14}$ We require non-missing observations for market value of equity and earnings before extraordinary items, and non-zero observations for special items. We also require firm-level sales not to be less than $\$ 1$ million because sales are used as a deflator for accounting variables. After imposing all data requirements, our final merged sample is from Q1:1974 to Q2:2014.

Figure 3 plots the timeline for measurement of our main variables. Both accounting earnings and GDP estimates are subject to a publication lag with their values for quarter $q$ being announced during quarter $q+1$. There are different GDP growth estimates during the quarter: the advance estimate, $r g d p_{q}^{a d v}$, the second estimate, $r g d p_{q}^{\text {second }}$, and the third estimate, $r g d p_{q}^{\text {third }}$, all of which are subsequently announced at the end of each month of the quarter. Our aggregate earnings variables, $e b s p i_{q}$ and $s p i_{q}$, are measured at a time that

\footnotetext{
${ }^{14}$ Given that there is a considerable delay in earnings announcements, we need to impose a restriction on the time at which accounting earnings is aggregated. We focus on earnings announced within 45 days after the end of the fiscal quarter because this approximately coincides with the deadline for the Form 10-Q and the time at which the SPF survey is issued.
} 
approximately coincides with the date at which the macro forecast of GDP, $E_{q}\left(r g d p_{q+n}\right)$, is made publicly available. Before that date, only $r g d p_{q}^{a d v}$ is available, and we use this estimate as a control variable in our OLS regressions. The revision in macro forecasts is measured as the difference between subsequent forecasts, $r e v_{q+n}=E_{q}\left(r g d p_{q+n}\right)-E_{q-1}\left(r g d p_{q+n}\right)$. Our one-quarter-ahead target variables, $r c p_{q+1}, r g$ diec $p_{q+1}$, and $r g d p_{q+1}$, become available in quarter $q+2$, and following other macroeconomics studies, we use the final estimate because it represents the most homogeneously measured and accurate estimate. ${ }^{15}$ Finally, news $q$ is the most timely variable in our setting and is measured during quarter $q$.

\section{[Insert Figure 3]}

Table 1 Panel A reports the summary statistics of the main variables and the results of the Phillips and Perron (1988) stationarity test. ${ }^{16}$ The Phillips-Perron test suggests that all series are stationary at conventional levels. Table 1 Panel B reports correlations among key variables. The results show that the correlation between $e b s p i_{q}$ and $s p i_{q}$ is negative and insignificant. $e b s p i_{q}$ has significant correlations with $r g d p_{q+1}$ and $r c p_{q+1}$ but insignificant correlation with rgdiec $p_{q+1} . s p i_{q}$ has significant correlations with $r g d p_{q+1}$ and $r g$ diec $p_{q+1}$ but insignificant correlation with $r c p_{q+1}$. In addition, the correlation between $n e w s_{q}$ and $s p i_{q}\left(e b s p i_{q}\right)$ is significant (insignificant). These univariate results provide preliminary evidence that aggregate earnings variables have different information content and suggest that aggregate special items is likely related to future real GDP growth through a distinctive pathway outside corporate profits.

\section{[Insert Table 1]}

\footnotetext{
${ }^{15}$ BEA publications and research indicate that the final GDP release is the BEA's best estimate because other releases are based on incomplete data and include errors (e.g., Landefeld, Seskin, and Fraumeni 2008; Fixler, Greenway-McGrevy, and Grimm 2011).

${ }^{16}$ We use the Phillips-Perron test instead of the augmented Dickey-Fuller test because the former corrects for heteroscedastic and serially correlated residuals (Hamilton 1994). We note that we also conduct a Phillip-Perron test for each variable in this study even if not listed within the key variables in Table 1. All our variables are stationary at conventional levels.
} 


\section{MAIN RESULTS}

\section{Aggregate Earnings Variables and Future Real GDP Growth}

\section{Real GDP Predictive Regressions}

Table 2 reports the results from estimating equation (1). The results reveal that both $e b s p i_{q}$ and $s p i_{q}$ contain useful information for future real GDP growth. However, the predictive power of $s p i_{q}$ is superior to that of $e b s p i_{q}$. For example, in the first column, for one-quarter-ahead GDP growth, the coefficient estimates are 0.078 and 0.187 with t-statistics of 4.27 and 3.17 for $e b s p i_{q}$ and $s p i_{q}$, respectively. Shapley values reveal that 9 percent of the model's adjusted R-squared is attributable to $e b s p i_{q}$ whereas $s p i_{q}$ accounts for a higher proportion of 28 percent. Not surprisingly, $r g d p_{q}^{a d v}$ makes the largest marginal contribution to the overall predictive ability of the model (i.e., 53 percent), followed by $s p i_{q}$.

In terms of economic significance, a one standard deviation change in $e b s p i_{q}\left(s p i_{q}\right)$ is associated with a change of approximately $50(80)$ basis points in one-quarter-ahead real GDP growth. The results in the second column are qualitatively similar when we measure inflation using CPI instead of PPI. Across all columns, for our earnings aggregates, only $s p i_{q}$ predicts future real GDP growth consistently and significantly and yields the highest Shapley values.

Overall, the results uncover the incremental role of aggregate special items as a leading predictor of future economic activity. This role is most pronounced for predicting subsequent quarter real GDP growth.

[Insert Table 2]

\section{Robustness Checks}

In this section, we examine the robustness of our previous findings using alternative model specifications and variable measurements. ${ }^{17}$

\footnotetext{
${ }^{17}$ To save space, we only report the results when PPI is the measure of inflation in these tests. Our inferences are unaffected when we use CPI.
} 


\section{Alternative controls of real GDP growth estimates and alternative earnings}

deflators. We use the advance real GDP growth estimate to control for autocorrelations in real GDP growth rates. The advance release of GDP growth has been used in previous macroaccounting research mainly because it becomes available during the time of the earnings aggregation window and before professional forecasts are released. The use of the current advance release as a control variable for the final release of real output in future quarters is also well-motivated in macroeconomics (Krusell and McKay 2010; Beaudry and Portier 2014; and Rodriguez Mora and Schulstad 2007). As a robustness check, Table 3 Panel A shows that using the second, third, or final estimates instead of the advance estimate does not affect our inferences.

In our baseline tests, we follow previous literature (Konchitchiki and Patatoukas 2014) and use firm-level sales to deflate our earnings variables. Table 3 Panel B shows that replacing sales by the market value of equity, total assets, or opening book value of equity as alternative earnings variables' deflators does not affect our inferences regarding aggregate special items.

\section{[Insert Table 3]}

Alternative time-series specifications. Macroeconomic variables exhibit significant levels of autocorrelation that could lead to spurious regression results when both the dependent and independent variables are non-stationary or highly persistent. In Table 1, we conduct a formal test to check the stationarity of our variables and find that all our variables are stationary as originally measured. However, to further ensure that our results are not driven by persistence in variables, we provide additional evidence using alternative time-series specifications. First, we transform all variables into serially uncorrelated shocks using autoregressive models of different orders. We then use these shock-form variables in our GDP predictive regressions and present the results in Table 4 Panel A. Our inferences regarding aggregate special items remain the same under this specification. The results show that the $s p i_{q}$ coefficient remains 
significant at the 5 percent level and, most importantly, $s p i_{q}$ is the only variable that maintains any predictive power among all independent variables. Second, we include up to three lagged values of our independent variables as additional controls and present the results in Table 4 Panel B. ${ }^{18}$ To conserve space, we only report the coefficients and t-statistics on the current values. Our main inferences are unaffected by using this alternative specification. These tests confirm that our main results for aggregate special items are unlikely to be driven by the level of persistence in variables. Notably, however, aggregate earnings before special items is relatively sensitive to measurement.

\section{[Insert Table 4]}

\section{Aggregate Earnings Variables, Professional Forecasts, and Rational Expectations}

\section{Professional Forecasts and Rational Expectations Test}

Table 5 reports the results from estimating equation (2). The results show that the $s p i_{q}$ coefficient remains significant after including the SPF macro forecasts, and the Shapley values indicate that $s p i_{q}$ contributes more to the predictive power of the model than $e b s p i_{q}$. For example, in the first column, for one-quarter-ahead GDP growth, the coefficient estimates are 0.033 and 0.114 with t-statistics of 1.75 and 2.70 for $e b s p i_{q}$ and $s p i_{q}$, respectively. Shapley values show that 2 percent ( 7 percent) of the model's adjusted R-squared is attributable to $\operatorname{ebspi}_{q}\left(s p i_{q}\right)$. This suggests that the macro forecast does not subsume information in aggregate special items.

\section{[Insert Table 5]}

Turning to the rational expectations test, Table 6 reports the results from estimating equations (3a) and (3b). The results reveal that professional forecasters fully impound information in aggregate earnings before special items but underestimate the information in

\footnotetext{
${ }^{18}$ In these robustness tests, we measure aggregate earnings before special items using a level specification instead of a change specification consistently with aggregate special items and then estimate the shocks or add lagged values.
} 
aggregate special items when predicting future real GDP growth. For example, in the first column, regarding one-quarter ahead GDP growth, the coefficient on $e b s p i_{q}$ is 0.078 in the GDP equation and 0.075 in the SPF revision equation, however the difference between the coefficients is not significant as indicated by the p-values. Meanwhile, the coefficient on $s p i_{q}$ is 0.187 in the GDP equation and 0.143 in the SPF revision equation and the difference between the coefficients is significant. We obtain similar evidence for all horizons considered. ${ }^{19}$

Although existing macro-accounting literature generally agrees on aggregate earnings providing incremental information not reflected in macro forecasts, there is no consensus on the reasons behind this apparent inefficiency. We put forward a compelling yet simple interpretation for this finding. The fact that economists at the BEA intentionally disregard special items from NIPA corporate profits suggests that macroeconomists consider special items to be potentially noisy and uninformative. Thus, it is not surprising to observe that professional forecasters do not fully incorporate information in special items when revising their real GDP growth forecasts.

\section{[Insert Table 6]}

\section{Robustness to Other Macroeconomic and Financial Information}

In our OLS regressions, we include current real GDP growth, inflation, and professional forecasts of real GDP growth. These controls are well motivated both theoretically and empirically and include a vast amount of information. For example, professional forecasters predicting future GDP growth likely take into account the information of a wide range of financial and macroeconomic indicators. By including these professional forecasts in our regressions, we implicitly incorporate this wide range of information as controls. Nevertheless,

\footnotetext{
${ }^{19}$ For a three-quarter-ahead horizon, although the perceived predictability of aggregate special items is less than the actual predictability, the difference is insignificant when the inflation control is PPI. However, when we use CPI instead of PPI, this difference is significant at the 5 percent level.
} 
in Table 7, we present results after including alternative macro indexes or individual macro series, in addition to professional forecasts.

We consider the following macro indexes: the Chicago Fed National Activity Index (CFNAI) from the Federal Reserve Bank of Chicago constructed using 85 monthly indicators of economic activity, the CFNAI's diffusion index constructed by placing more weight on the CFNAI's leading indicators, and the Atlanta Fed GDP index from the Federal Reserve Bank of Atlanta constructed by aggregating forecasts of 13 subcomponents comprising real GDP. In addition, we consider a set of individual macroeconomic and financial variables and their lags as defined in the notes of Table 7 . These variables include aggregate stock returns, aggregate book-to-market, term spread measured as the difference in quarterly interest rates between the ten-year constant maturity treasury bond and the one-year constant maturity treasury bill, default spread measured as the difference in quarterly interest rates between Moody's BAA and AAA bonds, Volatility Index (VIX) from the Chicago Board Options Exchange (CBOE), unemployment rate from the Bureau of Labor Statistics (BLS), oil price measured as the crude oil domestic first purchase price from the U.S. Energy Information Administration, industrial production, and quarterly media- and survey-based measures of macro uncertainty developed by Baker, Bloom, and Davis (2016) and Leduc and Liu (2016), respectively. ${ }^{20}$

The results show that controlling for additional macro indicators does not subsume the information content of aggregate special items. The $s p i_{q}$ coefficient ranges between 0.082 and 0.101 and is significant in all regressions. We note that our study is primarily focused on documenting and explaining why aggregate special items predicts future real GDP growth.

\footnotetext{
${ }^{20}$ The media-based measure of uncertainty is constructed using monthly scaled counts of uncertainty-related articles in ten leading US newspapers. We convert the monthly series to a quarterly series using a three-month average. The data are available at http://www.policyuncertainty.com/research.html. The survey-based measure of uncertainty is constructed using quarterly mean percentages of survey participants who responded "uncertain future" as a reason to postpone the purchase of durable goods in the Michigan Survey of Consumers. The data are available at https://data.sca.isr.umich.edu/.
} 
Nonetheless, documenting these incremental effects mitigates concerns about omitted correlated variables and strengthens our contribution.

\section{[Insert Table 7]}

\section{Macro News and the Predictive Ability of Aggregate Earnings Variables}

Table 8 reports the results from estimating equation (6). In the first column, we find that the coefficient on the interaction term $s p i_{q} \times n e w s_{q}$ is significant (i.e., $\kappa_{2}=0.343$ with tstatistic of 2.10) suggesting that the relation between aggregate special items and future real GDP growth is conditional on current macro news, as predicted. In the second column, when we replace $s p i_{q} \times n e w s_{q}$ with $s p i_{q} \times$ goodnews $_{q}$, we find that the coefficient on the interaction term is insignificant (i.e., $\kappa_{2}=-0.691$ with t-statistic of -1.41 ). Finally, in the third column, when we use $s p i_{q} \times b a d n e w s_{q}$, we find that the coefficient on the interaction term is significant (i.e., $\kappa_{2}=0.483$ with t-statistic 2.26 ). In contrast, the predictive ability of aggregate earnings before special items shows no sensitivity to news as $\kappa_{1}$ is insignificant across all specifications.

Overall, the results show that the association between aggregate special items and future GDP growth is conditional on the macro news. Subsequent analyses provide more evidence on the implications of news on the predictive ability of aggregate special items.

[Insert Table 8]

\section{AGGREGATE EARNINGS VARIABLES AND THE MACROECONOMY: VECTOR AUTOREGRESSION EVIDENCE}

\section{Accounting Earnings, NIPA Corporate Profits, and Gross Domestic Income}

Figure 4 reports the OIRFs of our VAR as described in equation (7). ${ }^{21}$ Following spi shocks, real GDP growth increases sharply and significantly. The effect is 0.7 percent $(0.6$

\footnotetext{
${ }^{21}$ All VARs include the SPF macro forecast. To disentangle the role of expectations in predicting GDP growth, we also show results for the same VAR after excluding the SPF macro forecast. In this case, we plot the OIRFs with and without SPF, as well as their confidence bands to show significance. If the information in aggregate earnings before special items is useful for predicting future GDP growth but this information is largely anticipated
} 
percent) in the first (second) quarter after the shock and remains significant until the third quarter. These effects are economically meaningful given that the average real GDP growth in our sample is 3 percent. In the meantime, ebspi shocks increase real GDP growth, but the effect is relatively smaller (i.e., 0.3 percent in the first quarter and 0.2 percent in the second quarter) and insignificant as indicated by the confidence bands. The response of real GDP growth to ebspi shocks is only significant when the VAR does not include the SPF macro forecast. This result further confirms our thesis that most of the information in aggregate earnings before special items is anticipated by professional forecasters. Interestingly, the effect of spi shocks on real GDP growth is even slightly larger when the VAR includes the SPF macro forecast. This indicates that the role of aggregate special items is largely unanticipated by professional forecasters. We also find that shocks to real GDP growth do not significantly affect aggregate earnings variables in subsequent quarters, as none of the OIRFs are significantly different from zero.

\section{[Insert Figure 4]}

In addition to the OIRFs, we report results on pairwise Granger causality tests and Forecast Error Variance Decompositions (FEVD) in Table 9 Panel A and Panel B, respectively. The former provides further evidence on the direction of causality between pairs of variables whereas the latter provides evidence on the economic significance of the variables' shocks. To conserve space, we only show results for lags and forecast horizons of $1,2,3,6$, and $10 .^{22}$

Table 9 Panel A shows that spi Granger-causes real GDP growth for three lags whereas ebspi does not Granger-cause real GDP, as indicated by the p-values. Moreover, there is no evidence that real GDP growth Granger-causes aggregate earnings variables. ${ }^{23}$ Table 9 Panel

\footnotetext{
by professional forecasters, we should find that ebspi shocks have significant effects after excluding the SPF macro forecast from the VAR.

${ }^{22}$ The change in the results after the third lag or forecast horizon is negligible. Therefore, in addition to three lags and forecast horizons, we report only those of 6 and 10 quarters.

${ }^{23}$ We acknowledge that managers could also recognize special items as a result of deteriorating past economic activity. A case for current GDP growth predicting future aggregate special items could be made if managers
} 
B shows that spi shocks account for a higher share of the forecast error variance of subsequent real GDP growth at all horizons relative to ebspi shocks. Specifically, a shock to spi (ebspi) explains 9.28 percent (1.22 percent) of the forecast error variance of real GDP growth over a ten-quarter horizon. In addition, real GDP growth explains a lower share of the forecast error variance of spi.

\section{[Insert Table 9]}

Figure 5 reports the OIRFs of an identical VAR after replacing real GDP growth with its income-side components: real GDI excluding corporate profits and real NIPA corporate profits. The results show that spi shocks have significant effects on future real GDI excluding corporate profits for up to six quarters ahead. Real GDI excluding corporate profits increases by 0.26 percent in the first quarter, reaches a peak of 0.35 percent in the third quarter, and then decreases dramatically. In contrast, ebspi shocks have significant effects on current real NIPA corporate profits increasing real profits by 1.32 percent but insignificant effects on future real NIPA corporate profits and future real GDI excluding corporate profits. Interestingly, when the SPF macro forecast is excluded from the VAR, the effect of ebspi shocks on corporate profits becomes significant and lasts up to three quarters ahead.

These results confirm the main hypotheses in our framework. First, aggregate earnings before special items acts as a proxy for NIPA corporate profits, affecting contemporaneous real GDP mechanically and future real GDP through persistence. However, the persistence effect is fully anticipated by professional forecasters. Second, aggregate special items reflects news about future macroeconomic outcomes outside NIPA corporate profits. Additionally, aggregate special items has only a delayed long-term effect on NIPA corporate profits, which appears to mainly track the path of GDI excluding corporate profits after the effect of news starts to fade.

\footnotetext{
delay the recognition of write-downs or other impairment charges. Another possibility is a sudden decrease in economic growth, which triggers the recognition of special items. Nevertheless, we do not observe evidence consistent with this directional prediction.
} 
[Insert Figure 5]

\section{Macro News shocks and Aggregate Accounting Earnings}

The time at which aggregate special items responds to macro news is key in understanding its ability to provide useful information about future economic prospects. We examine this response by augmenting our VAR in equation (7) with news and tracking the effect of news shocks on aggregate earnings variables. Figure 6 shows that news shocks are reflected in spi immediately, which in turn falls significantly by 0.90 percent and then rebounds quickly. In contrast, the response of ebspi to news shocks is insignificant. When we replace news with badnews and goodnews and re-estimate the VAR, we find that the immediate response of spi is mainly attributable to badnews shocks (i.e., spi falls significantly by 0.74 percent in the same quarter when badnews shocks hit and rather responds insignificantly to goodnews shocks). Overall, the results reveal that the response of aggregate special items to macro news shocks is timely, quickly reverting, and mainly attributable to bad news. Taken together with the evidence we document in previous sections, the results confirm that a relation between aggregate special items and future real GDP growth arises because the former captures advance news about future economic growth.

\section{[Insert Figure 6]}

\section{Aggregate Accounting Earnings and a Broader Set of Macro Aggregates}

A key property of the news theory in macroeconomics is that news shocks can induce comovement among a broad set of macro variables (Beaudry and Portier 2007; Barksy and Sims 2012). This is because the information received in advance by economic agents has the potential to change their incentives to invest, consume, or hire, and hence affects future economic development. Given our evidence that macro news is recognized in aggregate special items on a timely basis, we expect aggregate special items to be indicative of subsequent changes in a wide range of macroeconomic indicators, not limited to GDP growth. We examine 
this news propagation mechanism by expanding our VAR to include additional macroeconomic variables.

Figure 7 shows that spi shocks contain significant information about future investment, disposable income, unemployment, and consumption. Specifically, the response of investment (consumption) to $s p i$ shocks is immediate, reaches a peak equal to 1.20 percent ( 0.27 percent) after three (two) quarters, and remains significant for seven (four) quarters. These results are consistent with economic agents responding to news by altering their investment and consumption demand in anticipation of the economy's future development (Beaudry and Portier 2014). Unemployment (disposable income) reacts significantly to spi shocks, reaching a trough (peak) equal to 0.91 percent ( 0.23 percent) after two quarters (one quarter), and the effect remains significant for three (five) quarters. These results indicate that the news embedded in aggregate special items affects the labor market and consumer wealth with a short delay as firms change capacity in relation to changes in economic activity. In the meantime, ebspi shocks do not cause significant reactions in these variables except for an increase of 0.14 percent in consumption that is marginally significant after one quarter. In untabulated results, we find that the effect of ebspi shocks is significant only when the SPF macro forecast is excluded from the VAR but is always smaller than that of the spi shocks. ${ }^{24}$

These results have some implications for Hann et al. (2020), who provide evidence that aggregate special items forecasts future labor market conditions because it is associated with mass layoffs. In untabulated results, we further expand our VAR by including mass layoffs from the BLS and obtain very similar responses to those reported in Figure $7 .^{25}$ This indicates that, even after aggregate special items is orthogonalized with respect to unemployment or

\footnotetext{
${ }^{24}$ We thank one of the anonymous reviewers for suggesting that we include consumption, investment, and disposable income in our VAR. In an untabulated analysis, we also include additional macro variables such as exports, imports, and government spending and find that our inferences are unaffected.

${ }^{25}$ The mass layoffs variable is only available from Q2:1995 to Q2:2013 due to the abandonment of the mass layoffs program, which limits the sample for this additional test.
} 
mass layoffs, it continues to affect other macroeconomic variables, suggesting broader information content compared to that documented in Hann et al. (2020). These results further confirm that the labor market mechanism in Hann et al. (2020) does not subsume our news mechanism and that the information content of aggregate special items is not limited to the labor market.

\section{[Insert Figure 7]}

\section{CONCLUSION}

Aggregate special items reflects timely news about future economic conditions, which makes it forward-looking relative to other aggregate earnings components. Consequently, we find that aggregate special items explains significantly more of the variation in future real GDP growth than aggregate earnings before special items across a wide range of specifications. Being economically grounded, our news-based mechanism offers an alternative view to the corporate profit link presumed in the extant macro-accounting literature.

Using a two-stage rational expectations test, we document that professional forecasters fully understand the information content of aggregate earnings before special items but significantly underreact to information in aggregate special items. Given that economists at the BEA disregard special items when measuring NIPA corporate profits, our findings are consistent with aggregate special items being perceived by economists as lacking economic content. Using insights from news-driven theories of business cycles, we also demonstrate that the news embedded in aggregate special items has significant effects on a broad set of macroeconomic outcomes including investment, unemployment, consumption, and disposable income.

Our findings represent an important step towards understanding the role of aggregate accounting earnings in predicting future macroeconomic activity. The new insights we provide can help economists and policymakers to make more informed decisions. 


\section{REFERENCES}

Abel, A., and F. Mishkin. 1983. On the econometric testing of rationality-market efficiency. The Review of Economics and Statistics 65: 318-323

Alciatore, M., C. C. Dee, P. Easton, and N. Spear. 1998. Asset write-downs: A decade of research. Journal of Accounting Literature 17: 1-39.

Ali, A., and P. Zarowin. 1992. The role of earnings levels in annual earnings-returns studies. Journal of Accounting Research 30: 286-296.

Arif, S., and C. M. Lee. 2014. Aggregate investment and investor sentiment. Review of Financial Studies 27: 3241-3279.

Baker, S. R., N. Bloom, and S. J. Davis. 2016. Measuring economic policy uncertainty. The Quarterly Journal of Economics 131: 1593-1636.

Barsky, R. B., and E. R. Sims. 2011. News shocks and business cycles. Journal of Monetary Economics 58: 273-289

Barsky, R. B., and E. R. Sims. 2012. Information, animal spirits, and the meaning of innovations in consumer confidence. American Economic Review 102: 1343-1377.

Basu, S. 1997. The conservatism principle and the asymmetric timeliness of earnings. Journal of Accounting and Economics 25: 1-34.

Beaudry, P., and B. Lucke. 2010. Letting different views about business cycles compete. NBER Macroeconomics Annual 24: 413-45.

Beaudry, P., and F. Portier. 2006. Stock prices, news, and economic fluctuations. American Economic Review 96: 1293-1307.

Beaudry, P., and F. Portier. 2007. When can changes in expectations cause business cycle fluctuations in neo-classical settings? Journal of Economic Theory 135: 458-477.

Beaudry, P., and F. Portier. 2014. News-driven business cycles: Insights and challenges. Journal of Economic Literature 52: 993-1074.

Bloom, N. 2009. The impact of uncertainty shocks. Econometrica 77: 623-685.

Bureau of Economic Analysis (BEA). 2019. NIPA Handbook: Concepts and methods of the U.S. national income and product accounts. BEA, U.S. Department of Commerce.

Crawley, M. J. 2015. Macroeconomic consequences of accounting: The effect of accounting conservatism on macroeconomic indicators and the money supply. The Accounting Review 90: 987-1011.

Dichev, I. D. 2014. Explaining the changing properties of GAAP earnings: Insights from comparing GAAP to NIPA earnings. Working paper, Emory University.

Easton, P. D., and T. S. Harris. 1991. Earnings as an explanatory variable for returns. Journal of Accounting Research 29: 19-36.

Elliott, J. A., and J. D. Hanna. 1996. Repeated accounting write-offs and the information content of earnings. Journal of Accounting Research 34: 135-155.

Financial Times. 2020. Biggest U.S. oil refiner posts $\$ 9.2 \mathrm{bn}$ loss as fuel demand dives (May 5).

Financial Times. 2020. Lufthansa warns it will run out of cash in weeks (April 23).

Fixler, D. J., R. Greenway-McGrevy, and B. T. Grimm. 2011. Revisions to GDP, GDI, and their major components. Survey of Current Business 91: 9-31.

Francis, J., J. D. Hanna, and L. Vincent. 1996. Causes and effects of discretionary asset writeoffs. Journal of Accounting Research 34: 117-134.

Gaertner, F. B., A. Kausar, and L. B. Steele. 2020 Negative accounting earnings and gross domestic product. Review of Accounting Studies (Forthcoming).

Gallo, L. A., R. N. Hann, and C. Li. 2016. Aggregate earnings surprises, monetary policy, and stock returns. Journal of Accounting and Economics 62: 103-120.

Greene, W. H. 2012. Econometric analysis (7th ed.). London: Pearson 
Gow, I. D., G. Ormazabal, and D. J. Taylor. 2010. Correcting for cross-sectional and timeseries dependence in accounting research. The Accounting Review 85: 483-512.

Hamilton, J. D. 1994. Time series analysis. Princeton: Princeton University Press.

Hann, R. N., C. Li, and M. Ogneva. 2020. Another look at the macroeconomic information content of aggregate earnings: Evidence from the labor market. The Accounting Review (Forthcoming).

Jurado, K., S. Ludvigson, and S. Ng. 2015. Measuring uncertainty. The American Economic Review 3: 1177-1216

Konchitchki, Y., and P. N. Patatoukas. 2014. Accounting earnings and gross domestic product. Journal of Accounting and Economics 57: 76-88.

Kothari, S. P., J. Lewellen, and J. B. Warner. 2014. The behavior of aggregate corporate investment. Working Paper, Massachusetts Institute of Technology, Dartmouth College, and University of Rochester.

Krusell, P., and A. McKay. 2010. News shocks and business cycles. Economic Quarterly 96 : 373-397.

Landefeld, J. S., E. P. Seskin, and B. M. Fraumeni. 2008. Taking the pulse of the economy: Measuring GDP. Journal of Economic Perspectives 22: 193-216.

Leduc, S., and Z. Liu. 2016. Uncertainty shocks are aggregate demand shocks. Journal of Monetary Economics 82: 20-35.

Mishkin, F. 1983. A rational expectations approach to macroeconomics: Testing policy effectiveness and efficient market models. Chicago, IL: University of Chicago Press for the National Bureau of Economic Research.

Nallareddy, S., and M. Ogneva. 2017. Predicting restatements in macroeconomic indicators using accounting information. The Accounting Review 92: 151-182

Newey, W. K., and K. D. West. 1987. A Simple, positive semi-definite, heteroskedasticity and autocorrelation. Econometrica 55: 703-708.

Nordhaus, W. 2002. The recent recession, the current recovery, and stock prices. Brookings Papers on Economic Activity 1: 199-220.

Phillips, P. C., and P. Perron. 1988. Testing for a unit root in time series regression. Biometrika 75: 335-346.

Pigou, A. 1927. Industrial fluctuations. MacMillan, London.

Rodriguez Mora, J. V., and P. Schulstad. 2007. The effect of GNP announcements on fluctuations of GNP growth. European Economic Review 51: 1922-1940.

Shapley, L. S., 1953. A value for n-person games. Contributions to the Theory of Games 28: 307-317.

Shorrocks, A. F. 2013. Decomposition procedures for distributional analysis: a unified framework based on the Shapley value. The Journal of Economic Inequality 11: 99-126.

Shivakumar, L. 2007. Aggregate earnings, stock market returns, and macroeconomic activity: A discussion of 'Does earnings guidance affect market returns? The nature and information content of aggregate earnings guidance'. Journal of Accounting and Economics 44: 64-73.

Shivakumar, L., and O. Urcan. 2017. Why does aggregate earnings growth reflect information about future inflation? The Accounting Review 92: 247-276.

Sloan, R. G. 1996. Do stock prices fully reflect information in accruals and cash flows about future earnings? The Accounting Review 71: 289-315.

Stock, J. H., and M. W. Watson. 2001. Vector autoregressions. Journal of Economic perspectives 15: 101-115.

Wall Street Journal. 2019. No-deal Brexit could spur U.K. goodwill impairment. (March 7). 


\begin{tabular}{|c|c|}
\hline Variable & Definition \\
\hline$e b s p i_{q}$ & $\begin{array}{l}\text { Aggregate earnings before special items. We measure firm-level earnings before special items as the year-over-year change in scaled quarterly earnings } \\
\text { before extraordinary items (Compustat item ibq) less special items (Compustat item spiq). Following Konchitchiki and Patatoukas (2014), we scale } \\
\text { firm-level earnings by sales (Compustat item saleq) to avoid negative denominator problems. To create a time-series variable, we aggregate firm-level } \\
\text { earnings before special items using value-weighted cross-sectional averages, with weights based on market value as of the beginning of the quarter. } \\
\text { We consider alternative deflators and alternative time-series specifications in robustness tests, as indicated in the text in the relevant sections. }\end{array}$ \\
\hline$s p i_{q}$ & $\begin{array}{l}\text { Aggregate special items. We measure firm-level special items as scaled quarterly special items (Compustat item spiq). We scale firm-level special } \\
\text { items by sales. To create a time-series variable, we aggregate firm-level special items using value-weighted cross-sectional averages, with weights } \\
\text { based on market value as of the beginning of the quarter. We consider alternative deflators and alternative time-series specifications in robustness tests, } \\
\text { as indicated in the text in the relevant sections. }\end{array}$ \\
\hline$r g d p_{q}^{a d v}$ & $\begin{array}{l}\text { The advance (i.e., first) release of real GDP growth by the Bureau of Economic Analysis (BEA). We collect the GDP data from the Real-Time Data } \\
\text { Research Center of the Federal Reserve Bank of Philadelphia. GDP data can be accessed at https://www.philadelphiafed.org/research-and-data/real- } \\
\text { time-center/real-time-data/data-files/first-second-third. }\end{array}$ \\
\hline$i n f_{q}(p p i)$ & $\begin{array}{l}\text { Producer Price Index growth (PPI) from the Bureau of Labor Statistics (BLS). We convert the monthly series to a quarterly series using a three-month } \\
\text { average. }\end{array}$ \\
\hline $\inf f_{q}(c p i)$ & Consumer Price Index growth (CPI) from the BLS. We convert the monthly series to a quarterly series using a three-month average. \\
\hline unem $_{q}$ & The unemployment rate from the BLS, filtered using the Hodrick-Prescott (HP) filter with a smoothing parameter of 1600. \\
\hline int $_{q}$ & $\begin{array}{l}\text { Interest rate equal to the year-over-year change in quarterly interest rate on the one-year constant maturity treasury bill from the Federal Reserve Bank } \\
\text { of St. Louis Economic Data (FRED). We convert the monthly series to a quarterly series using a three-month average. }\end{array}$ \\
\hline news $q$ & $\begin{array}{l}\text { Macro news based on participants' responses to a question from the Michigan Survey of Consumers on whether recent "news heard" about the } \\
\text { macroeconomy is favorable, goodnews } \text {, or unfavorable, badnews } \text { news }_{q} \text { is measured as the unfavorable news index minus the favorable news } \\
\text { index plus } 100 \text {. }\end{array}$ \\
\hline$E_{q}\left(r g d p_{q+n}\right)$ & $\begin{array}{l}\text { The mean macro forecast of real GDP growth for quarter } q+n \text { from the Survey of Professional Forecasters (SPF). For simplicity, we sometimes refer } \\
\text { to this variable as SPF. }\end{array}$ \\
\hline$r g d p_{q+n}$ & The final release of real GDP growth rate for quarter $q+n$ by the BEA. \\
\hline$r c p_{q+1}$ & $\begin{array}{l}\text { National Income and Product Accounts (NIPA) corporate profit growth in real terms. Quarterly nominal corporate profits are obtained from Line } 17 \\
\text { of the NIPA Table 1.7.5. We use the GDP deflator from Line } 1 \text { of the NIPA Table } 1.1 .9 \text { to convert nominal corporate profits into real values. We } \\
\text { calculate growth rates as the year-over-year percentage change in real corporate profits. }\end{array}$ \\
\hline $\operatorname{rgdiec}_{q+1}$ & $\begin{array}{l}\text { Gross Domestic Income (GDI) growth excluding corporate profits in real terms. Quarterly nominal GDI is obtained from Line } 26 \text { of the NIPA Table } \\
\text { 1.7.5. We use the GDP deflator from Line } 1 \text { of the NIPA Table 1.1.9 to convert nominal GDI into real values, and then subtract real corporate profits. } \\
\text { We calculate growth rates as the year-over-year percentage change in real GDI excluding corporate profits. }\end{array}$ \\
\hline $\begin{array}{l}\operatorname{consump}_{q} \\
\text { dispincome }_{q}\end{array}$ & $\begin{array}{l}\text { Aggregate consumption from Line } 2 \text { of the NIPA Table 1.1.3. We calculate growth rates as the year-over-year percentage change in consumption. } \\
\text { Real disposable income as percent change from one year ago from FRED. }\end{array}$ \\
\hline invest $_{q}$ & $\begin{array}{l}\text { Aggregate non-residential investment from Line } 9 \text { of the NIPA Table 1.1.3. We calculate growth rates as the year-over-year percentage change in } \\
\text { investment. }\end{array}$ \\
\hline
\end{tabular}


Table 1

Descriptive Statistics

Panel A: Summary Statistics and the Phillips-Perron Test of Stationarity

\begin{tabular}{|c|c|c|c|c|c|c|}
\hline & Mean & SD & $\mathrm{p} 25$ & Median & p75 & PP test \\
\hline$e b s p i_{q}$ & 0.01 & 0.06 & -0.01 & 0.00 & 0.02 & 0.00 \\
\hline$s p i_{q}$ & -0.02 & 0.04 & -0.03 & -0.02 & 0.00 & 0.00 \\
\hline$r g d p_{q}^{a d v}$ & 0.02 & 0.03 & 0.01 & 0.02 & 0.04 & 0.00 \\
\hline$i n f_{q}(p p i)$ & 0.01 & 0.01 & 0.00 & 0.01 & 0.02 & 0.00 \\
\hline $\operatorname{news}_{q}$ & 1.28 & 0.29 & 1.10 & 1.22 & 1.43 & 0.00 \\
\hline$r g d p_{q+1}$ & 0.03 & 0.03 & 0.01 & 0.03 & 0.04 & 0.00 \\
\hline$r c p_{q+1}$ & 0.04 & 0.13 & -0.06 & 0.05 & 0.12 & 0.00 \\
\hline $\operatorname{rgdiec}_{q+1}$ & 0.03 & 0.02 & 0.01 & 0.03 & 0.04 & 0.01 \\
\hline
\end{tabular}

Panel B: Correlations

\begin{tabular}{|c|c|c|c|c|c|c|c|}
\hline & $e b s p i_{q}$ & $s p i_{q}$ & $r g d p_{q}^{a d v}$ & $i n f_{q}(p p i)$ & news $_{q}$ & $r g d p_{q+1}$ & $r c p_{q+1}$ \\
\hline$s p i_{q}$ & -0.11 & & & & & & \\
\hline$r g d p_{q}^{a d v}$ & 0.04 & 0.09 & & & & & \\
\hline$i n f_{q}(p p i)$ & 0.01 & 0.20 & -0.13 & & & & \\
\hline $\operatorname{news}_{q}$ & -0.10 & -0.24 & -0.62 & 0.17 & & & \\
\hline$r g d p_{q+1}$ & 0.13 & 0.22 & 0.37 & -0.13 & -0.50 & & \\
\hline$r c p_{q+1}$ & 0.15 & 0.03 & 0.49 & -0.19 & -0.42 & 0.48 & \\
\hline rgdiec $p_{q+1}$ & -0.02 & 0.30 & 0.54 & -0.04 & -0.67 & 0.43 & 0.11 \\
\hline
\end{tabular}

This table reports descriptive statistics for the main variables. Panel A presents summary statistics and the pvalues associated with the Phillips-Perron (PP) stationarity test. Panel B presents Pearson pairwise correlations. Values in bold indicate statistical significance at the 10 percent level or higher. All variables are defined in the Appendix. The sample includes 161 quarters from Q1:1974 to Q2:2014. The advance release of GDP growth is unavailable in Q4:1994 due to government shutdown. 
Table 2

Aggregate Earnings Variables and Future Real GDP Growth

$r g d p_{q+n}=\alpha+\beta_{1} e b s p i_{q}+\beta_{2} s p i_{q}+\lambda_{1} r g d p_{q}^{a d v}+\lambda_{2} i n f_{q}+\varepsilon_{q+n}$

\begin{tabular}{|c|c|c|c|c|c|c|c|c|c|c|c|c|}
\hline \multirow[b]{3}{*}{ Constant } & \multicolumn{2}{|c|}{$r g d p_{q+1}$} & \multicolumn{2}{|c|}{$r g d p_{q+1}$} & \multicolumn{2}{|c|}{$r g d p_{q+2}$} & \multicolumn{2}{|c|}{$r g d p_{q+2}$} & \multicolumn{2}{|c|}{$r g d p_{q+3}$} & \multicolumn{2}{|c|}{$r g d p_{q+3}$} \\
\hline & Coeff. & ShpR $^{2}$ & Coeff. & ShpR $^{2}$ & Coeff. & ShpR $^{2}$ & Coeff. & $\begin{array}{l}\text { ShpR }^{2} \\
\end{array}$ & Coeff. & ShpR $^{2}$ & Coeff. & ShpR $^{2}$ \\
\hline & $\begin{array}{l}0.027 * * * \\
(5.84)\end{array}$ & & $\begin{array}{l}0.032 * * * \\
(5.95)\end{array}$ & & $\begin{array}{l}0.032 * * * \\
(5.95)\end{array}$ & & $\begin{array}{l}0.036^{* * *} \\
(6.48)\end{array}$ & & $\begin{array}{l}0.037 * * * \\
(8.07)\end{array}$ & & $\begin{array}{l}0.037 * * * \\
(7.20)\end{array}$ & \\
\hline$e b s p i_{q}$ & $\begin{array}{l}0.078^{* * *} \\
(4.27)\end{array}$ & $9 \%$ & $\begin{array}{l}0.079^{* * *} \\
(4.19)\end{array}$ & $9 \%$ & $\begin{array}{l}0.036 \\
(1.65)\end{array}$ & $4 \%$ & $\begin{array}{l}0.037^{*} \\
(1.70)\end{array}$ & $4 \%$ & $\begin{array}{l}0.063^{*} \\
(1.71)\end{array}$ & $13 \%$ & $\begin{array}{l}0.061^{*} \\
(1.71)\end{array}$ & $21 \%$ \\
\hline$s p i_{q}$ & $\begin{array}{l}0.187 * * * \\
(3.17)\end{array}$ & $28 \%$ & $\begin{array}{l}0.204 * * * \\
(3.55)\end{array}$ & $29 \%$ & $\begin{array}{l}0.130^{* *} \\
(2.35)\end{array}$ & $24 \%$ & $\begin{array}{l}0.145^{* * *} \\
(2.76)\end{array}$ & $26 \%$ & $\begin{array}{l}0.132 * * * \\
(2.64)\end{array}$ & $21 \%$ & $\begin{array}{l}0.124 * * \\
(2.45)\end{array}$ & $32 \%$ \\
\hline$r g d p_{q}^{a d v}$ & $\begin{array}{l}0.322 * * * \\
(3.86)\end{array}$ & $53 \%$ & $\begin{array}{l}0.304 * * * \\
(3.57)\end{array}$ & $48 \%$ & $\begin{array}{l}0.136 \\
(1.15)\end{array}$ & $28 \%$ & $\begin{array}{c}0.122 \\
(1.01)\end{array}$ & $25 \%$ & $\begin{array}{r}-0.000 \\
(-0.00)\end{array}$ & $3 \%$ & $\begin{array}{c}0.010 \\
(0.09)\end{array}$ & $5 \%$ \\
\hline $\inf f_{q}(p p i)$ & $\begin{array}{l}-0.384^{* *} \\
(-1.98)\end{array}$ & $10 \%$ & & & $\begin{array}{l}-0.570^{* * *} \\
(-2.66)\end{array}$ & $44 \%$ & & & $\begin{array}{l}-0.691 * * * \\
(-3.27)\end{array}$ & $63 \%$ & & \\
\hline$i n f_{q}(c p i)$ & & & $\begin{array}{l}-0.748^{* *} \\
(-2.26)\end{array}$ & $14 \%$ & & & $\begin{array}{l}-0.928^{* * *} \\
(-3.02)\end{array}$ & $46 \%$ & & & $\begin{array}{l}-0.703^{* *} \\
(-2.14)\end{array}$ & $42 \%$ \\
\hline Adj. $\mathrm{R}^{2}$ & $19 \%$ & & $20 \%$ & & $7 \%$ & & $7 \%$ & & $6 \%$ & & $3 \%$ & \\
\hline Nobs. & 161 & & 161 & & 160 & & 160 & & 159 & & 159 & \\
\hline
\end{tabular}

This table reports results from time-series regressions of future real GDP growth on aggregate earnings variables. All variables are defined in the Appendix. The sample contains quarterly data from Q1:1974 to Q2:2014. Reported t-statistics are based on Newey-West HAC standard errors with a lag length of four. ***, **,* denote significance at the 1,5 , and 10 percent levels, respectively, using two-tailed tests. Shapley values (ShpR $\left.{ }^{2}\right)$ are additive decompositions of the adjusted $\mathrm{R}^{2}$ of the regression model and show the relative contribution of each independent variable to the model's adjusted $\mathrm{R}^{2}$. 
Table 3

Robustness: Real GDP Growth Estimates and Earnings Deflators

Panel A: Alternative Current Quarter's Real GDP Growth Controls

\begin{tabular}{|c|c|c|c|}
\hline & $\operatorname{rgdp}_{q+1}$ & $\operatorname{rgdp_{q+1}}$ & $\operatorname{rgdp}_{q+1}$ \\
\hline Constant & $\begin{array}{l}0.027 * * * \\
(5.99)\end{array}$ & $\begin{array}{l}0.027 * * * \\
(6.13)\end{array}$ & $\begin{array}{l}0.026^{* * *} \\
(6.26)\end{array}$ \\
\hline$e b s p i_{q}$ & $\begin{array}{l}0.077 * * * \\
(4.26)\end{array}$ & $\begin{array}{l}0.077 * * * \\
(4.31)\end{array}$ & $\begin{array}{l}0.074 * * * \\
(4.23)\end{array}$ \\
\hline$s p i_{q}$ & $\begin{array}{l}0.181 \text { *** } \\
(3.14)\end{array}$ & $\begin{array}{l}0.179 \text { *** } \\
(3.16)\end{array}$ & $\begin{array}{l}0.181 * * * \\
(3.39)\end{array}$ \\
\hline$r g d p_{q}^{\text {second }}$ & $\begin{array}{l}0.295 * * * \\
(3.64)\end{array}$ & & \\
\hline$r g d p_{q}^{\text {third }}$ & & $\begin{array}{l}0.289^{* * *} \\
(3.71)\end{array}$ & \\
\hline$r g d p_{q}$ & & & $\begin{array}{l}0.305^{* * *} \\
(3.57)\end{array}$ \\
\hline$i n f_{q}(p p i)$ & $\begin{array}{l}-0.406^{* *} \\
(-2.09)\end{array}$ & $\begin{array}{l}-0.416^{* *} \\
(-2.15)\end{array}$ & $\begin{array}{l}-0.431 * * \\
(-2.26)\end{array}$ \\
\hline Adj. $\mathrm{R}^{2}$ & $18 \%$ & $18 \%$ & $19 \%$ \\
\hline
\end{tabular}

Panel B: Alternative Earnings Deflators

\begin{tabular}{|c|c|c|c|}
\hline & Market value as a deflator & Total assets as a deflator & Book value as a deflator \\
\hline & $r g d p_{q+1}$ & $r g d p_{q+1}$ & $r g d p_{q+1}$ \\
\hline Constant & $\begin{array}{l}0.025^{* * * *} \\
(5.98)\end{array}$ & $\begin{array}{l}0.024 * * * \\
(5.18)\end{array}$ & $\begin{array}{l}0.025^{* * * *} \\
(5.00)\end{array}$ \\
\hline ebspi $i_{q}$ & $\begin{array}{l}0.369^{* *} \\
(2.00)\end{array}$ & $\begin{array}{c}0.441 \\
(0.54)\end{array}$ & $\begin{array}{r}0.013 \\
(0.28)\end{array}$ \\
\hline$s p i_{q}$ & $\begin{array}{l}0.378^{* * *} \\
(3.76)\end{array}$ & $\begin{array}{l}0.974 * * \\
(2.06)\end{array}$ & $\begin{array}{l}0.369 * * * \\
(2.64)\end{array}$ \\
\hline$r g d p_{q}^{a d v}$ & $\begin{array}{l}0.327^{* * *} \\
(4.06)\end{array}$ & $\begin{array}{l}0.417^{* * *} \\
(3.90)\end{array}$ & $\begin{array}{l}0.343^{* * *} \\
(3.62)\end{array}$ \\
\hline$i n f_{q}(p p i)$ & $\begin{array}{c}-0.269 \\
(-1.29)\end{array}$ & $\begin{array}{l}-0.375^{*} \\
(-1.68)\end{array}$ & $\begin{array}{c}-0.341 \\
(-1.60)\end{array}$ \\
\hline Adj. $\mathrm{R}^{2}$ & $20 \%$ & $13 \%$ & $15 \%$ \\
\hline
\end{tabular}

This table reports results from time-series regressions of future real GDP growth on aggregate earnings variables after including different estimates of real GDP growth in Panel A and using alternative earnings deflators in Panel B. In Panel A, $g d p_{q}^{\text {second }}, r g d p_{q}^{\text {third }}$, and $r g d p_{q}$ are the second, third, and final estimates of real GDP growth from the Real-Time Data Research Center of the Federal Reserve Bank of Philadelphia. In Panel B, we use market value, total assets, and opening book value as alternative earnings deflators to sales. All other variables are defined in the Appendix. The sample includes 161 quarters from Q1:1974 to Q2:2014. Reported t-statistics are based on NeweyWest HAC standard errors with a lag length of four. ***,**,* denote significance at the 1,5 , and 10 percent levels, respectively, using two-tailed tests. 
Table 4

Robustness: Alternative Time-Series Specifications

Panel A: Shock-to-Shock Analysis

\begin{tabular}{|c|c|c|c|}
\hline & $\mathrm{AR}(1)$ residuals & $\mathrm{AR}(2)$ residuals & AR(3) residuals \\
\hline & $r g d p_{q+1}$ & $r g d p_{q+1}$ & $r g d p_{q+1}$ \\
\hline \multirow[t]{2}{*}{ Constant } & 0.000 & 0.000 & 0.000 \\
\hline & $(0.06)$ & $(0.05)$ & $(0.04)$ \\
\hline \multirow{2}{*}{$e b s p i_{q}$} & -0.011 & -0.000 & 0.022 \\
\hline & $(-0.10)$ & $(-0.00)$ & $(0.21)$ \\
\hline \multirow{2}{*}{$s p i_{q}$} & $0.127 * *$ & $0.117 * *$ & $0.123 * *$ \\
\hline & $(2.47)$ & $(2.21)$ & $(2.38)$ \\
\hline \multirow[t]{2}{*}{$r g d p_{q}^{a d v}$} & 0.043 & 0.065 & 0.063 \\
\hline & $(0.43)$ & $(0.69)$ & $(0.66)$ \\
\hline \multirow[t]{2}{*}{$\inf f_{q}(p p i)$} & -0.272 & -0.263 & -0.277 \\
\hline & $(-1.31)$ & $(-1.25)$ & $(-1.30)$ \\
\hline Adj. $R^{2}$ & $1 \%$ & $1 \%$ & $1 \%$ \\
\hline Nobs. & 161 & 160 & 159 \\
\hline
\end{tabular}

Panel B: Alternative Specification Including Lagged Values of All Variables

\begin{tabular}{|c|c|c|c|}
\hline & One lag & Two lags & Three lags \\
\hline & $r g d p_{q+1}$ & $r g d p_{q+1}$ & $r g d p_{q+1}$ \\
\hline Constant & $\begin{array}{l}0.035 * * * \\
(444)\end{array}$ & $0.043 * * *$ & $0.045 * * *$ \\
\hline$e b s p i_{q}$ & $\begin{array}{l}-0.054 \\
(-0.61)\end{array}$ & $\begin{array}{c}-0.028 \\
(-0.30)\end{array}$ & $\begin{array}{c}0.032 \\
(0.33)\end{array}$ \\
\hline$s p i_{q}$ & $\begin{array}{l}0.139^{* *} \\
(2.48)\end{array}$ & $\begin{array}{l}0.154 * * * \\
(2.68)\end{array}$ & $\begin{array}{l}0.163 * * * \\
(2.85)\end{array}$ \\
\hline$r g d p_{q}^{a d v}$ & $\begin{array}{l}0.321^{* * * *} \\
(3.91)\end{array}$ & $\begin{array}{l}0.286 * * * \\
(3.61)\end{array}$ & $\begin{array}{l}0.288^{* * *} \\
(3.42)\end{array}$ \\
\hline$i n f_{q}(p p i)$ & $\begin{array}{c}-0.258 \\
(-1.16)\end{array}$ & $\begin{array}{c}-0.302 \\
(-1.28)\end{array}$ & $\begin{array}{c}-0.377 \\
(-1.43)\end{array}$ \\
\hline Adj. $\mathrm{R}^{2}$ & $16 \%$ & $16 \%$ & $17 \%$ \\
\hline Nobs. & 161 & 160 & 159 \\
\hline
\end{tabular}

This table reports results from time-series regressions of future real GDP growth on aggregate earnings variables using alternative time-series specifications. Panel A presents the results when the independent and dependent variables are measured as residuals from autoregressive models with different lag lengths [i.e., AR(1), AR(2), and AR(3)] and time trend. Panel B presents the results for an alternative specification that includes lags. In these robustness tests, we measure aggregate earnings before special items using a level specification instead of a change specification consistently with aggregate special items and then estimate the shocks or add lagged values. All other variables are defined in the Appendix. The sample contains quarterly data from Q1:1974 to Q2:2014. Reported t-statistics are based on Newey-West HAC standard errors with a lag length of four. ***,**, * denote significance at the 1, 5, and 10 percent levels, respectively, using two-tailed tests 
Table 5

Aggregate Earnings Variables and Professional Macro Forecasts

$r g d p_{q+n}=\alpha+\beta_{1} e b s p i_{q}+\beta_{2} s p i_{q}+\lambda_{1} r g d p_{q}^{a d v}+\lambda_{2} i n f_{q}+\lambda_{3} E_{q}\left(r g d p_{q+n}\right)+\varepsilon_{q+n}$

\begin{tabular}{|c|c|c|c|c|c|c|c|c|c|c|c|c|}
\hline & \multicolumn{2}{|c|}{$r g d p_{q+1}$} & \multicolumn{2}{|c|}{$r g d p_{q+1}$} & \multicolumn{2}{|c|}{$r g d p_{q+2}$} & \multicolumn{2}{|c|}{$r g d p_{q+2}$} & \multicolumn{2}{|c|}{$r g d p_{q+3}$} & \multicolumn{2}{|c|}{$r g d p_{q+3}$} \\
\hline & Coeff. & ShpR $^{2}$ & Coeff. & ShpR $^{2}$ & Coeff. & ShpR $^{2}$ & Coeff. & ShpR $^{2}$ & Coeff. & ShpR $^{2}$ & Coeff. & ShpR $^{2}$ \\
\hline Constant & $0.009 * *$ & & 0.005 & & $0.011^{*}$ & & $0.011 *$ & & $0.013 * *$ & & 0.010 & \\
\hline & $(2.38)$ & & (1.11) & & (1.72) & & $(1.76)$ & & $(2.17)$ & & $(1.26)$ & \\
\hline$e b s p i_{q}$ & $\begin{array}{l}0.033^{*} \\
(1.75)\end{array}$ & $2 \%$ & $\begin{array}{r}0.030 \\
(1.49)\end{array}$ & $2 \%$ & $\begin{array}{c}0.013 \\
(0.75)\end{array}$ & $1 \%$ & $\begin{array}{c}0.012 \\
(0.74)\end{array}$ & $1 \%$ & $\begin{array}{l}0.053^{*} \\
(1.78)\end{array}$ & $5 \%$ & $\begin{array}{l}0.050^{*} \\
(1.76)\end{array}$ & $6 \%$ \\
\hline$s p i_{q}$ & $\begin{array}{l}0.114^{* * *} \\
(2.70)\end{array}$ & $7 \%$ & $\begin{array}{l}0.097 * * \\
(2.24)\end{array}$ & $7 \%$ & $\begin{array}{l}0.088^{*} \\
(1.86)\end{array}$ & $7 \%$ & $\begin{array}{l}0.084 * * \\
(2.01)\end{array}$ & $7 \%$ & $\begin{array}{l}0.117 * * * \\
(2.66)\end{array}$ & $9 \%$ & $\begin{array}{l}0.098 * * \\
(2.12)\end{array}$ & $9 \%$ \\
\hline$r g d p_{q}^{a d v}$ & $\begin{array}{l}-0.225^{* * *} \\
(-2.80)\end{array}$ & $13 \%$ & $\begin{array}{l}-0.227 * * * \\
(-2.74)\end{array}$ & $13 \%$ & $\begin{array}{l}-0.046 \\
(-0.43)\end{array}$ & $7 \%$ & $\begin{array}{l}-0.042 \\
(-0.39)\end{array}$ & $7 \%$ & $\begin{array}{c}-0.021 \\
(-0.21)\end{array}$ & $1 \%$ & $\begin{array}{l}-0.002 \\
(-0.02)\end{array}$ & $1 \%$ \\
\hline$i n f_{q}(p p i)$ & $\begin{array}{l}-0.084 \\
(-0.55)\end{array}$ & $2 \%$ & & & $\begin{array}{r}-0.287 \\
(-1.46)\end{array}$ & $11 \%$ & & & $\begin{array}{l}-0.520^{* *} \\
(-2.40)\end{array}$ & $24 \%$ & & \\
\hline$i n f_{q}(c p i)$ & & & $\begin{array}{c}0.156 \\
(0.65)\end{array}$ & $3 \%$ & & & $\begin{array}{l}-0.285 \\
(-0.93)\end{array}$ & $11 \%$ & & & $\begin{array}{c}-0.316 \\
(-0.80)\end{array}$ & $8 \%$ \\
\hline$E_{q}\left(r g d p_{q+1}\right)$ & $\begin{array}{l}1.229 * * * \\
(8.28)\end{array}$ & $75 \%$ & $\begin{array}{l}1.270^{* * *} \\
(7.94)\end{array}$ & $74 \%$ & & & & & & & & \\
\hline$E_{q}\left(r g d p_{q+2}\right)$ & & & & & $\begin{array}{l}0.852 * * * \\
(5.55)\end{array}$ & $74 \%$ & $\begin{array}{l}0.855^{* * * *} \\
(5.29)\end{array}$ & $74 \%$ & & & & \\
\hline$E_{q}\left(r g d p_{q+3}\right)$ & & & & & & & & & $\begin{array}{l}0.805^{* * * *} \\
(4.13)\end{array}$ & $61 \%$ & $\begin{array}{l}0.851 \text { *** } \\
(4.20)\end{array}$ & $75 \%$ \\
\hline Adj. $\mathrm{R}^{2}$ & $51 \%$ & & $51 \%$ & & $20 \%$ & & $19 \%$ & & $15 \%$ & & $12 \%$ & \\
\hline Nobs. & 161 & & 161 & & 160 & & 160 & & 159 & & 159 & \\
\hline
\end{tabular}

This table reports results from time-series regressions of future real GDP growth on aggregate earnings variables and professional macro forecasts of real GDP growth from the Survey of Professional Forecasters (SPF). All variables are defined in the Appendix. The sample contains quarterly data from Q1:1974 to Q2:2014. Reported t-statistics are based on Newey-West HAC standard errors with a lag length of four. ***, **,* denote significance at the 1, 5, and 10 percent levels, respectively, using two-tailed tests. Shapley values $\left(\mathrm{ShpR}^{2}\right)$ are additive decompositions of the adjusted $\mathrm{R}^{2}$ of the regression model and show the relative contribution of each independent variable to the model's adjusted $\mathrm{R}^{2}$ 
Table 6

Aggregate Earnings and Macro Forecast Revisions: A Two-Stage Rational Expectations Test

$r g d p_{q+n}=\alpha+\beta_{1} e b s p i_{q}+\beta_{2} s p i_{q}+\lambda_{1} r g d p_{q}^{a d v}+\lambda_{2} i n f_{q}+e_{q+n}$

$r e v_{q+n}=r g d p_{q+n}-\alpha^{*}-\beta_{1}^{*} e b s p i_{q}-\beta_{2}^{*} s p i_{q}-\lambda_{1}^{*} r g d p_{q}^{a d v}-\lambda_{2}^{*} i n f_{q}+u_{q+n}$

\begin{tabular}{|c|c|c|c|c|c|c|}
\hline GDP equation & \multicolumn{2}{|c|}{$r g d p_{q+1}$} & \multicolumn{2}{|c|}{$r g d p_{q+2}$} & \multicolumn{2}{|c|}{$r g d p_{q+3}$} \\
\hline Constant & $\begin{array}{l}0.027 * * * \\
(6.83)\end{array}$ & $\begin{array}{l}0.032 * * * \\
(6.48)\end{array}$ & $\begin{array}{l}0.032 * * * \\
(7.58)\end{array}$ & $\begin{array}{l}0.036 * * * \\
(6.99)\end{array}$ & $\begin{array}{l}0.037^{* * * *} \\
(8.70)\end{array}$ & $\begin{array}{l}0.037 * * * \\
(6.87)\end{array}$ \\
\hline$e b s p i_{q}$ & $\begin{array}{l}0.078^{* *} \\
(2.09)\end{array}$ & $\begin{array}{l}0.079 * * \\
(2.14)\end{array}$ & $\begin{array}{c}0.036 \\
(0.91)\end{array}$ & $\begin{array}{r}0.037 \\
(0.94)\end{array}$ & $\begin{array}{c}0.063 \\
(1.57)\end{array}$ & $\begin{array}{c}0.061 \\
(1.50)\end{array}$ \\
\hline$s p i_{q}$ & $\begin{array}{l}0.187 * * * \\
(3.33)\end{array}$ & $\begin{array}{l}0.204 * * * \\
(3.60)\end{array}$ & $\begin{array}{l}0.130 * * \\
(2.20)\end{array}$ & $\begin{array}{l}0.145^{* *} \\
(2.41)\end{array}$ & $\begin{array}{l}0.132^{* *} \\
(2.20)\end{array}$ & $\begin{array}{l}0.124^{* *} \\
(1.99)\end{array}$ \\
\hline$r g d p_{q}^{a d v}$ & $\begin{array}{l}0.322 * * * \\
(4.10)\end{array}$ & $\begin{array}{l}0.304^{* * *} \\
(3.87)\end{array}$ & $\begin{array}{l}0.136^{*} \\
(1.65)\end{array}$ & $\begin{array}{c}0.122 \\
(1.47)\end{array}$ & $\begin{array}{c}-0.000 \\
(-0.01)\end{array}$ & $\begin{array}{c}0.010 \\
(0.12)\end{array}$ \\
\hline$i n f_{q}(p p i)$ & $\begin{array}{l}-0.384 * * \\
(-1.97)\end{array}$ & & $\begin{array}{l}-0.570^{* * *} \\
(-2.78)\end{array}$ & & $\begin{array}{l}-0.691 * * * \\
(-3.32)\end{array}$ & \\
\hline $\inf f_{q}(c p i)$ & & $\begin{array}{l}-0.748 * * \\
(-2.52)\end{array}$ & & $\begin{array}{l}-0.928 * * * \\
(-2.95)\end{array}$ & & $\begin{array}{l}-0.703 * * \\
(-2.16)\end{array}$ \\
\hline SPF revision equation & \multicolumn{2}{|c|}{$r e v_{q+1}$} & \multicolumn{2}{|c|}{$r e v_{q+2}$} & \multicolumn{2}{|c|}{$r e v_{q+3}$} \\
\hline Constant & $\begin{array}{l}0.031 * * * \\
(9.20)\end{array}$ & $\begin{array}{l}0.034 * * * \\
(7.94)\end{array}$ & $\begin{array}{l}0.034 * * * \\
(8.51)\end{array}$ & $\begin{array}{l}0.036^{* * * *} \\
(7.22)\end{array}$ & $\begin{array}{l}0.037 * * * \\
(9.34)\end{array}$ & $\begin{array}{l}0.035^{* * *} \\
(6.90)\end{array}$ \\
\hline$e b s p i_{q}$ & $\begin{array}{l}0.075^{* *} \\
(2.31)\end{array}$ & $\begin{array}{l}0.075^{* *} \\
(2.33)\end{array}$ & $\begin{array}{r}0.029 \\
(0.78)\end{array}$ & $\begin{array}{r}0.029 \\
(0.78)\end{array}$ & $\begin{array}{r}0.057 \\
(1.53)\end{array}$ & $\begin{array}{r}0.055 \\
(1.44)\end{array}$ \\
\hline$s p i_{q}$ & $\begin{array}{l}0.143 \text { *** } \\
(2.95)\end{array}$ & $\begin{array}{l}0.150 * * * \\
(3.04)\end{array}$ & $\begin{array}{l}0.101^{*} \\
(1.78)\end{array}$ & $\begin{array}{l}0.106^{*} \\
(1.82)\end{array}$ & $\begin{array}{l}0.116^{* *} \\
(2.07)\end{array}$ & $\begin{array}{l}0.099 * \\
(1.69)\end{array}$ \\
\hline$r g d p_{q}^{a d v}$ & $\begin{array}{l}0.201 * * * \\
(2.98)\end{array}$ & $\begin{array}{l}0.194 * * * \\
(2.84)\end{array}$ & $\begin{array}{c}0.050 \\
(0.64)\end{array}$ & $\begin{array}{c}0.046 \\
(0.58)\end{array}$ & $\begin{array}{l}-0.010 \\
(-0.12)\end{array}$ & $\begin{array}{c}0.010 \\
(0.13)\end{array}$ \\
\hline$i n f_{q}(p p i)$ & $\begin{array}{l}-0.327 * \\
(-1.95)\end{array}$ & & $\begin{array}{l}-0.418^{* *} \\
(-2.12)\end{array}$ & & $\begin{array}{l}-0.526 * * * \\
(-2.71)\end{array}$ & \\
\hline $\inf f_{q}(c p i)$ & & $\begin{array}{l}-0.518^{* *} \\
(-2.01)\end{array}$ & & $\begin{array}{l}-0.584^{*} \\
(-1.92)\end{array}$ & & $\begin{array}{l}-0.352 \\
(-1.15)\end{array}$ \\
\hline Nobs. & 161 & 161 & 160 & 160 & 159 & 159 \\
\hline
\end{tabular}


Table 6 (Continued)

Aggregate Earnings and Macro Forecast Revisions: A Two-Stage Rational Expectations Test

Professional forecasters'

rational expectations test

$\beta_{1}^{*}-\beta_{1}$

$\mathrm{p}$-value

$\beta_{2}^{*}-\beta_{2}$

$-0.003$

0.83

$-0.044$

0.05

-0.004
0.77
-0.054
0.02

-0.007
0.51
-0.029

-0.008
0.44
-0.039
0.01
$-0.006$
0.50
-0.016

$-0.006$

0.40

0.04

$-0.025$

0.03

This table reports results from a joint system of GDP predictive equation and macro forecast revisions equation. The system is estimated using non-linear least squares. Revisions in macro forecasts of future real GDP growth are measured as $r e v_{q+n}=E_{q}\left(r g d p_{q+n}\right)-E_{q-1}\left(r g d p_{q+n}\right)$. All other variables are defined in the Appendix. The sample contains quarterly data from Q1:1974 to Q2:2014. ***,**,* denote significance at the 1, 5, and 10 percent levels, respectively, using two-tailed tests. 
Table 7

Robustness: Professional Macro Forecasts, Macro Indexes, and Individual Financial and Macroeconomic Series

\begin{tabular}{|c|c|c|c|c|}
\hline & $\begin{array}{c}\text { Chicago Fed National Activity } \\
\text { Index (CFNAI:85 series) }\end{array}$ & $\begin{array}{c}\text { Chicago Fed Diffusion } \\
\text { Index (Leading CFNAI series) }\end{array}$ & $\begin{array}{c}\text { Atlanta Fed GDP } \\
\text { Index (13 forecasts) }\end{array}$ & $\begin{array}{c}\text { Individual financial and } \\
\text { macroeconomic series }\end{array}$ \\
\hline & $r g d p_{q+1}$ & $r g d p_{q+1}$ & $r g d p_{q+1}$ & $r g d p_{q+1}$ \\
\hline \multirow[t]{2}{*}{ Constant } & $0.013 * * *$ & $0.018 * * *$ & $0.014 * * *$ & $0.027 *$ \\
\hline & $(2.81)$ & $(6.15)$ & $(2.98)$ & $(1.77)$ \\
\hline \multirow[t]{2}{*}{$e b s p i_{q}$} & 0.027 & 0.029 & 0.025 & 0.056 \\
\hline & $(1.50)$ & $(1.31)$ & $(1.31)$ & $(1.02)$ \\
\hline \multirow[t]{2}{*}{$s p i_{q}$} & $0.100 * *$ & $0.082 * *$ & $0.084 * *$ & $0.101 * * *$ \\
\hline & $(2.44)$ & (1.99) & (1.98) & $(2.85)$ \\
\hline \multirow{2}{*}{$r g d p_{q}^{a d v}$} & $-0.205^{* *}$ & $-0.296 * * *$ & $-0.192 * *$ & $-0.217 * *$ \\
\hline & $(-2.31)$ & $(-3.87)$ & $(-2.14)$ & $(-2.30)$ \\
\hline \multirow[t]{2}{*}{$i n f_{q}(p p i)$} & -0.060 & -0.129 & -0.055 & -0.345 \\
\hline & $(-0.44)$ & $(-1.15)$ & $(-0.41)$ & $(-1.58)$ \\
\hline \multirow{2}{*}{$E_{q}\left(r g d p_{q+1}\right)$} & $1.003 * * *$ & $0.793 * * *$ & $0.929 * * *$ & $1.040 * * *$ \\
\hline & $(4.65)$ & $(5.42)$ & $(4.14)$ & $(3.48)$ \\
\hline \multirow{2}{*}{ index $_{q}$} & $0.007 * *$ & $0.036 * * *$ & $0.008 * * *$ & \\
\hline & $(2.27)$ & $(8.14)$ & $(2.67)$ & \\
\hline Adj. $\mathrm{R}^{2}$ & $53 \%$ & $60 \%$ & $54 \%$ & $50 \%$ \\
\hline Nobs. & 161 & 161 & 161 & 113 \\
\hline
\end{tabular}

This table reports results from time-series regressions of future real GDP growth on aggregate earnings variables and macro forecasts after including additional controls. index $q$ is either the Chicago Fed National Activity Index (CFNAI), the diffusion index, or the Atlanta Fed GDP index, measured in the second month of the quarter in which earnings is announced. The controls in the last column are as follows. Aggregate stock returns measured as the value-weighted cross-sectional average of firm-level quarterly returns. Firm-level quarterly returns are from CRSP and computed by aggregating monthly returns starting one month before the end of the quarter. Aggregate book-to-market where firm-level book-to-market is the quarterly book value of equity from Compustat divided by previous quarter market value from CRSP. For aggregate returns and book-tomarket, we include one and two lags in addition to current values. Term spread measured as the difference in quarterly interest rates between the ten-year constant maturity treasury bond and the one-year constant maturity treasury bill. Default spread measured as the difference in quarterly interest rates between Moody's BAA and AAA bonds. Volatility Index (VIX) from the Chicago Board Options Exchange (CBOE). VIX is not available before 1990. Therefore, we follow previous research (e.g., Bloom 2009; Jurado, Ludvigson, and Ng 2015) and use CBOE S\&P100 VXO for observations before 1990 (available from Q2:1986), which limits the sample. Unemployment rate from the Bureau of Labor Statistics (BLS). Oil price measured as the crude oil domestic first purchase price from the U.S. Energy Information Administration. Unemployment and oil series are filtered using the HP filter with a smoothing parameter of 1600. Industrial production measured as the first release of industrial production from the Federal Reserve Bank of Philadelphia. Finally, we include a quarterly media-based measure of uncertainty developed by Baker et al. (2016) and a quarterly survey-based measure of uncertainty developed by Leduc and Liu (2016) using information from the Michigan Survey of Consumers. To conserve space, the coefficients on the individual macroeconomic or financial series are not reported. All other variables are defined in the Appendix. The sample contains quarterly data from Q1:1974 to Q2:2014. Reported t-statistics are based on Newey-West HAC standard errors with a lag length of four. ***,**,* denote significance at the 1,5 , and 10 percent levels, respectively, using two-tailed tests. 
Table 8

Macro News and the Predictive Ability of Aggregate Earnings Variables

$$
\begin{aligned}
r g d p_{q+1}= & \alpha+\hat{\beta}_{1} \operatorname{ebspi}_{q}+\grave{\beta}_{2} s p i_{q}+\lambda_{1} r g d p_{q}^{a d v}+\lambda_{2} \inf _{q}+\kappa_{1} \text { ebspi }_{q} \times n e w s_{q} \\
& +\kappa_{2} \operatorname{spi}_{q} \times n e w s_{q}+\varepsilon_{q+1}
\end{aligned}
$$

\begin{tabular}{|c|c|c|c|}
\hline & $r g d p_{q+1}$ & $r g d p_{q+1}$ & $r g d p_{q+1}$ \\
\hline Constant & $\begin{array}{l}0.029 * * * \\
(6.14)\end{array}$ & $\begin{array}{l}0.027^{* * *} \\
(5.84)\end{array}$ & $\begin{array}{l}0.030^{* * *} \\
(6.12)\end{array}$ \\
\hline$e b s p i_{q}$ & $\begin{array}{c}-0.090 \\
(-0.49)\end{array}$ & $\begin{array}{c}0.166 \\
(1.27)\end{array}$ & $\begin{array}{c}-0.021 \\
(-0.18)\end{array}$ \\
\hline$s p i_{q}$ & $\begin{array}{c}-0.318 \\
(-1.46)\end{array}$ & $\begin{array}{l}0.331 * * \\
(2.33)\end{array}$ & $\begin{array}{c}-0.143 \\
(-1.11)\end{array}$ \\
\hline$r g d p_{q}^{a d v}$ & $\begin{array}{l}0.273 * * * \\
(3.40)\end{array}$ & $\begin{array}{l}0.304 * * * \\
(3.80)\end{array}$ & $\begin{array}{l}0.266^{* * *} \\
(3.29)\end{array}$ \\
\hline$i n f_{q}(p p i)$ & $\begin{array}{l}-0.485^{* *} \\
(-2.32)\end{array}$ & $\begin{array}{l}-0.389^{* *} \\
(-1.98)\end{array}$ & $\begin{array}{l}-0.519^{* *} \\
(-2.39)\end{array}$ \\
\hline$e b s p i_{q} \times \operatorname{news}_{q}$ & $\begin{array}{r}0.121 \\
(0.73)\end{array}$ & & \\
\hline$s p i_{q} \times n e w s_{q}$ & $\begin{array}{l}0.343^{* *} \\
(2.10)\end{array}$ & & \\
\hline$e b s p i_{q} \times$ goodnews $_{q}$ & & $\begin{array}{c}-0.328 \\
(-0.86)\end{array}$ & \\
\hline$s p i_{q} \times$ goodnews $q$ & & $\begin{array}{c}-0.691 \\
(-1.41)\end{array}$ & \\
\hline ebspi $_{q} \times$ badnew $_{q}$ & & & $\begin{array}{c}0.152 \\
(0.60)\end{array}$ \\
\hline$s p i_{q} \times$ badnews $_{q}$ & & & $\begin{array}{l}0.483 * * \\
(2.26)\end{array}$ \\
\hline Adj. $R^{2}$ & $20 \%$ & $19 \%$ & $21 \%$ \\
\hline
\end{tabular}

This table reports results from time-series regressions of future real GDP growth on aggregate earnings variables and the interaction of aggregate earnings variables with macro news. All variables are defined in the Appendix. The sample includes 161 quarters from Q1:1974 to Q2:2014. Reported t-statistics are based on Newey-West HAC standard errors with a lag length of four. $* * *, * * *$ denote significance at the 1,5 , and 10 percent levels, respectively, using twotailed tests. 
Table 9

Causality Tests and Forecast Error Variance Decompositions of the Vector Autoregression

Panel A: Pairwise Granger Causality

\begin{tabular}{|c|c|c|c|c|c|c|c|c|c|}
\hline \multirow{2}{*}{\multicolumn{2}{|c|}{$\begin{array}{l}\text { Regressor } \\
\text { Dependent }\end{array}$}} & \multicolumn{2}{|c|}{$\begin{array}{l}\text { rgdp } \\
\text { ebspi }\end{array}$} & \multicolumn{2}{|c|}{$\begin{array}{c}\text { rgdp } \\
\text { spi }\end{array}$} & \multicolumn{2}{|c|}{$\begin{array}{l}\text { ebspi } \\
\text { rgdp }\end{array}$} & \multicolumn{2}{|c|}{$\begin{array}{c}\text { spi } \\
\operatorname{rgdp}\end{array}$} \\
\hline & & $x^{2}$ & p-value & $x^{2}$ & p-value & $x^{2}$ & p-value & $x^{2}$ & p-value \\
\hline \multirow[t]{5}{*}{ Lag } & 1 & 0.52 & 0.47 & 0.63 & 0.43 & 1.30 & 0.26 & $5.94 * *$ & 0.02 \\
\hline & 2 & 1.01 & 0.60 & 1.73 & 0.42 & 2.95 & 0.23 & $6.54 * *$ & 0.04 \\
\hline & 3 & 0.55 & 0.91 & 2.89 & 0.41 & 3.40 & 0.33 & $7.53 *$ & 0.06 \\
\hline & 6 & 1.46 & 0.96 & 1.96 & 0.92 & 4.57 & 0.60 & 8.35 & 0.21 \\
\hline & 10 & 2.74 & 0.99 & 6.68 & 0.76 & 10.16 & 0.43 & 7.62 & 0.67 \\
\hline
\end{tabular}

Panel B: Forecast Error Variance Decomposition (FEVD)

\begin{tabular}{|c|c|c|c|c|c|}
\hline \multicolumn{2}{|c|}{ Impulse } & $r g d p$ & $r g d p$ & ebspi & spi \\
\hline \multirow{2}{*}{\multicolumn{2}{|c|}{ Response }} & ebspi & spi & $r g d p$ & $\operatorname{rgdp}$ \\
\hline & & FEVD in \% & FEVD in \% & FEVD in $\%$ & FEVD in $\%$ \\
\hline \multirow{5}{*}{ Horizon } & 1 & 0.00 & 0.00 & 0.02 & 0.57 \\
\hline & 2 & 0.30 & 0.34 & 1.07 & 6.62 \\
\hline & 3 & 0.30 & 0.33 & 1.24 & 9.06 \\
\hline & 6 & 0.30 & 0.35 & 1.24 & 9.36 \\
\hline & 10 & 0.30 & 0.36 & 1.22 & 9.28 \\
\hline
\end{tabular}

This table reports results from Granger causality tests in Panel A and variance decompositions in Panel B after fitting a VAR of inflation, unemployment, interest rate, macro forecast of real GDP growth, aggregate earnings variables, and real GDP growth, as per Figure 4. All variables are defined in the Appendix. The sample contains quarterly data from Q1:1974 to Q2:2014. ***,**,* denote significance at the 1, 5, and 10 percent levels, respectively, using twotailed tests. 
Figure 1

Time Series of Aggregate Special Items and Major Bad Economic Events

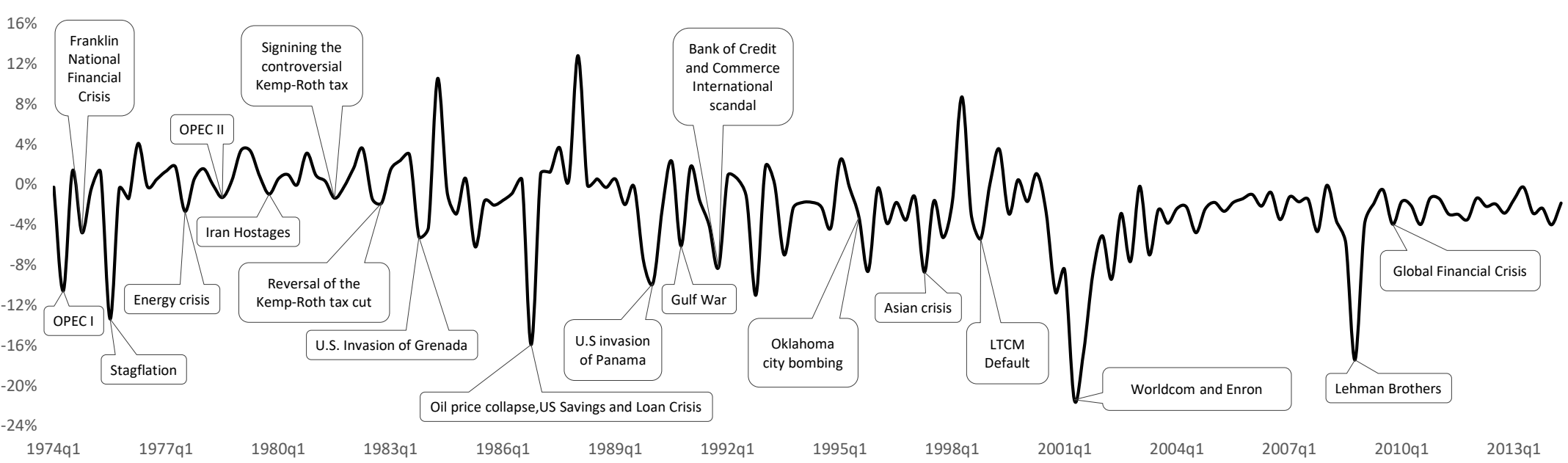

This figure shows the time series of aggregate special items and major bad economic events in the US. Aggregate special items is the value-weighted cross-sectional average of scaled quarterly firm-level special items with weights based on market value as of the beginning of the quarter. 
Figure 2

A Framework for Aggregate Earnings Variables and Future Economic Growth

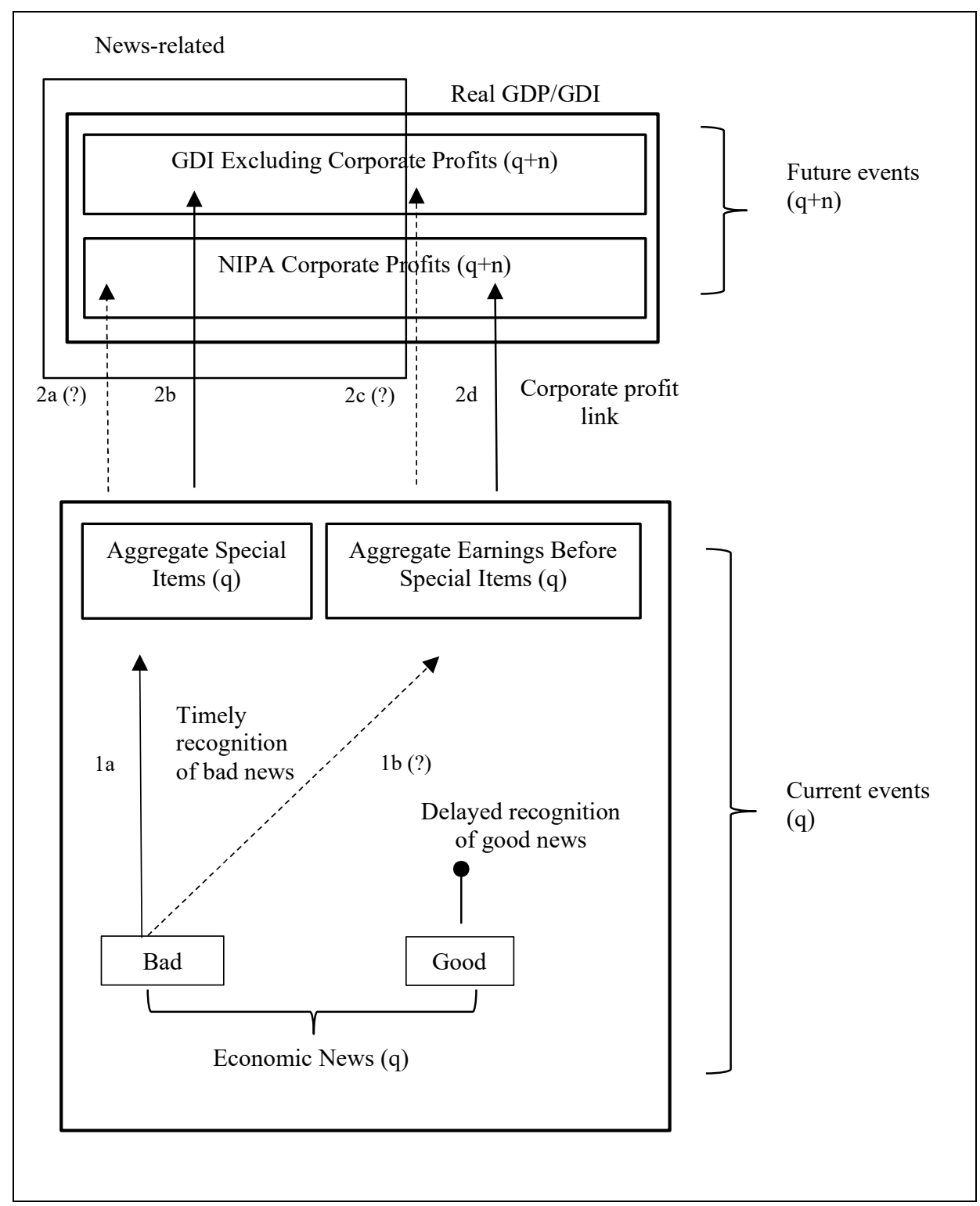

This figure shows a framework for the relations among macro news, aggregate earnings variables, GDP growth, and income-based components of GDP. 
Figure 3

Timeline for Key Variable Measurement

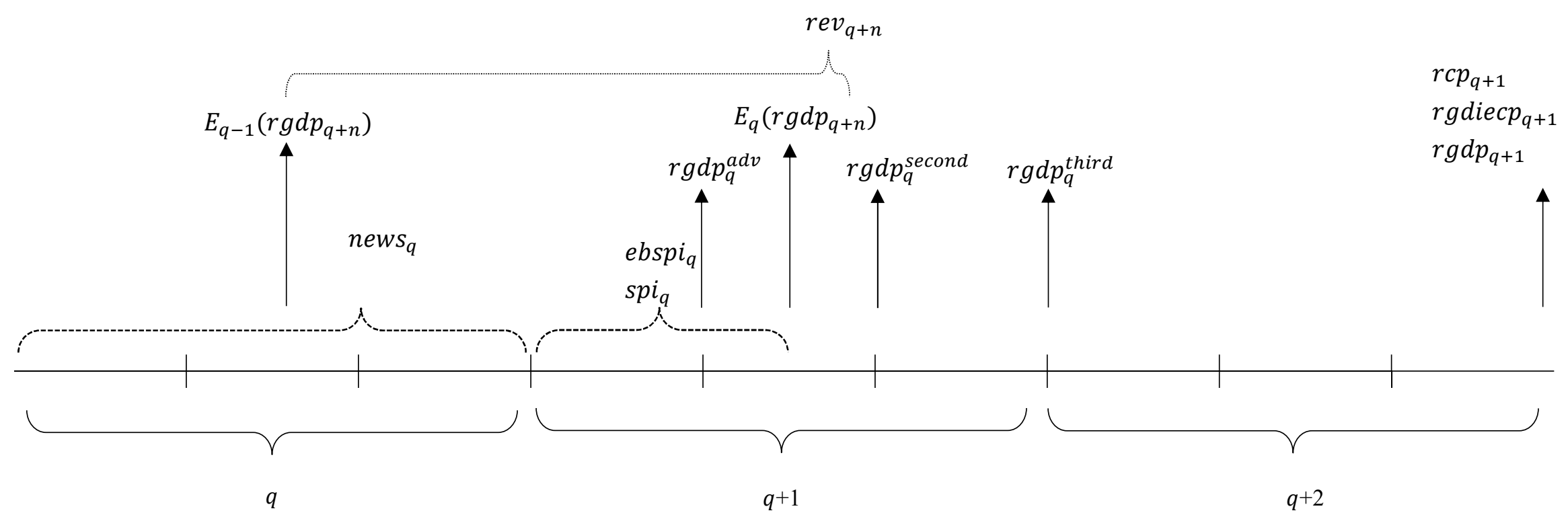

This figure shows the timeline for measurement of our main variables. Both accounting earnings and GDP estimates are subject to a publication lag. GDP estimates and accounting earnings for any given quarter $q$ will be announced during quarter $q+1$. There are three different GDP estimates during the quarter: the advance estimate, $r g d p_{q}^{a d v}$, the second estimate, $r g d p_{q}^{\text {second }}$, and the third estimate, $r g d p_{q}^{\text {third }}$, all of which are announced subsequently at the end of each month of the quarter. To construct our accounting earnings variables, $e b s p i_{q}$ and $s p i_{q}$, we collect accounting information for firms that announce earnings within the first 45 days of the quarter. This time approximately coincides with the date at which the macro forecast of GDP, $E_{q}\left(r g d p_{q+n}\right)$, is made publicly available. Revisions in macro forecasts of future real GDP growth are measured as $r e v_{q+n}=E_{q}\left(r g d p_{q+n}\right)-E_{q-1}\left(r g d p_{q+n}\right)$. Our one-quarter-ahead target variables, $r c p_{q+1}, r g d i e c p_{q+1}$, and $r g d p_{q+1}$, become available in quarter $q+2$, and are the final estimates. All variables are defined in the Appendix. 


\section{Figure 4}

\section{Vector Autoregression Analysis: Aggregate Earnings Variables and Real GDP Growth}

$Y_{q+1}=A+B Y_{q}+\varepsilon_{q+1}$ where $Y_{q}=\left(\inf _{q}(p p i)\right.$, unem $\left._{q}, i n t_{q}, E_{q}\left(r g d p_{q+1}\right), s p i_{q}, e b s p i_{q}, r g d p_{q}\right)$
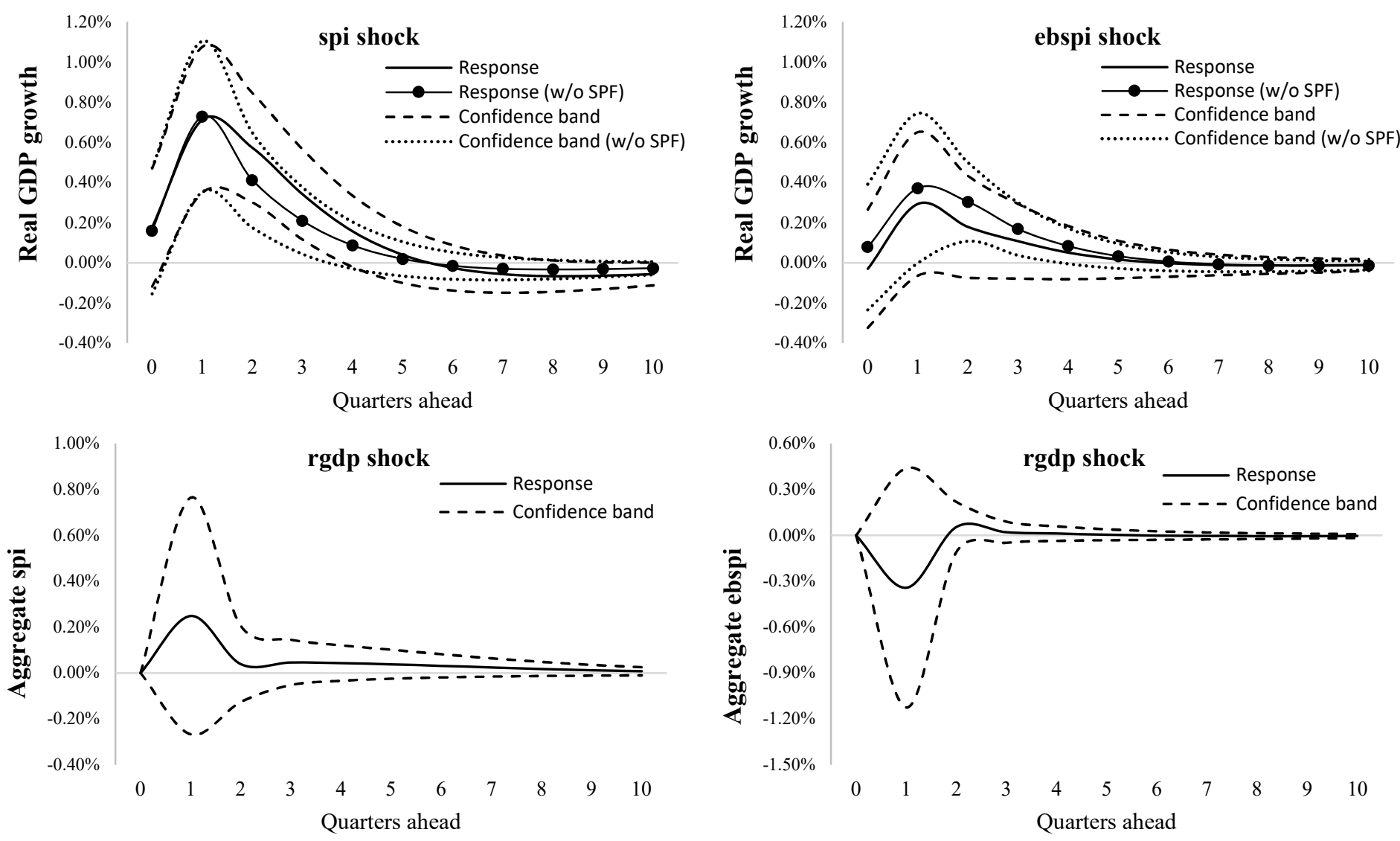

This figure shows the OIRFs' results from a VAR of inflation, unemployment, interest rate, expected real GDP growth from the SPF, aggregate earnings variables, and real GDP growth. All variables are defined in the Appendix. The confidence bands represent 90 percent confidence level. 


\section{Figure 5}

Vector Autoregression Analysis: Aggregate Earnings Variables and Income-based GDP Components
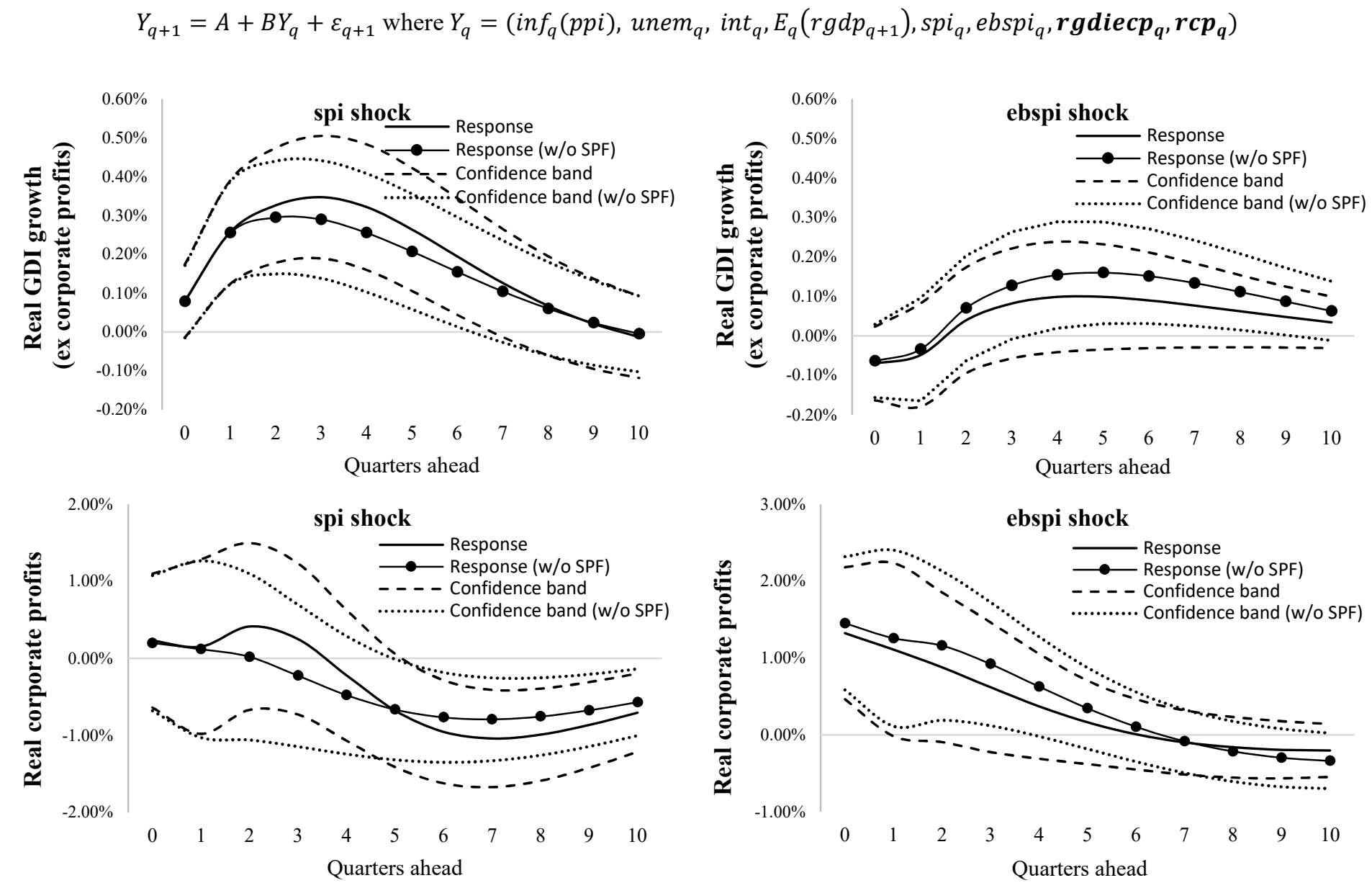

This figure shows the OIRFs' results from a VAR of inflation, unemployment, interest rate, expected real GDP growth from the SPF, aggregate earnings variables, and incomebased real GDP growth components. All variables are defined in the Appendix. The confidence bands represent 90 percent confidence level. 


\section{Figure 6}

\section{Vector Autoregression Analysis: Macro News and Aggregate Earnings Variables}

$$
Y_{q+1}=A+B Y_{q}+\varepsilon_{q+1} \text { where } Y_{q}=\left(\boldsymbol{n e w s}_{q}, \text { inf }_{q}(p p i), \text { unem }_{q}, \text { int }_{q}, E_{q}\left(r g d p_{q+1}\right), \text { spi }_{q}, \operatorname{ebspi}_{q}, r g d p_{q}\right)
$$

\section{Panel A: News Effect}
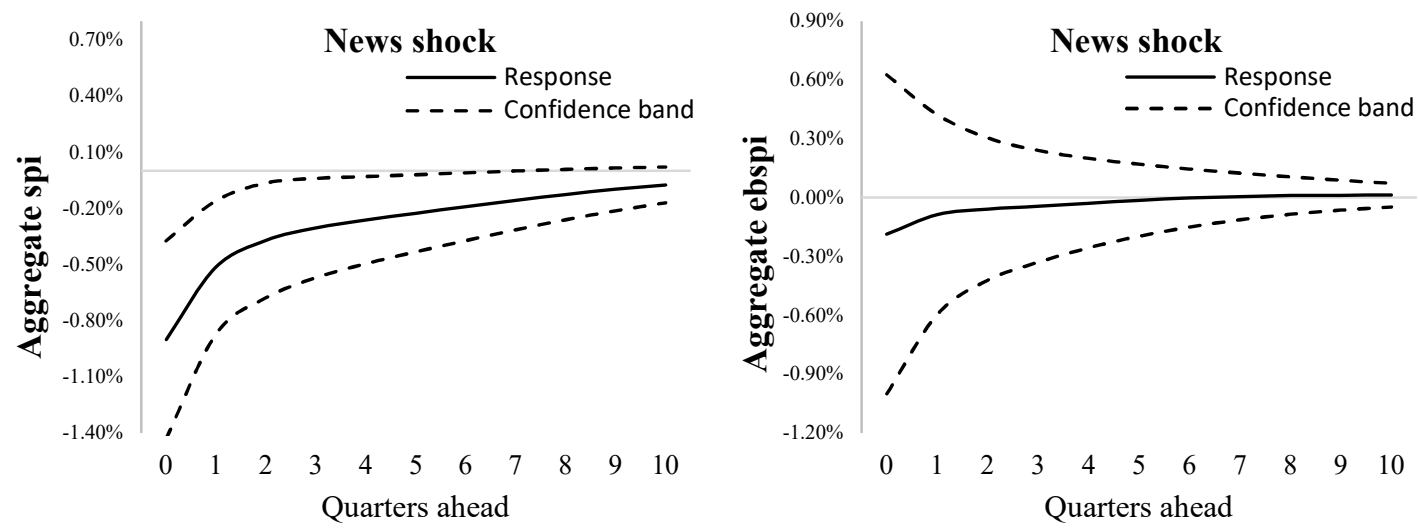

Panel B: Bad News Effect
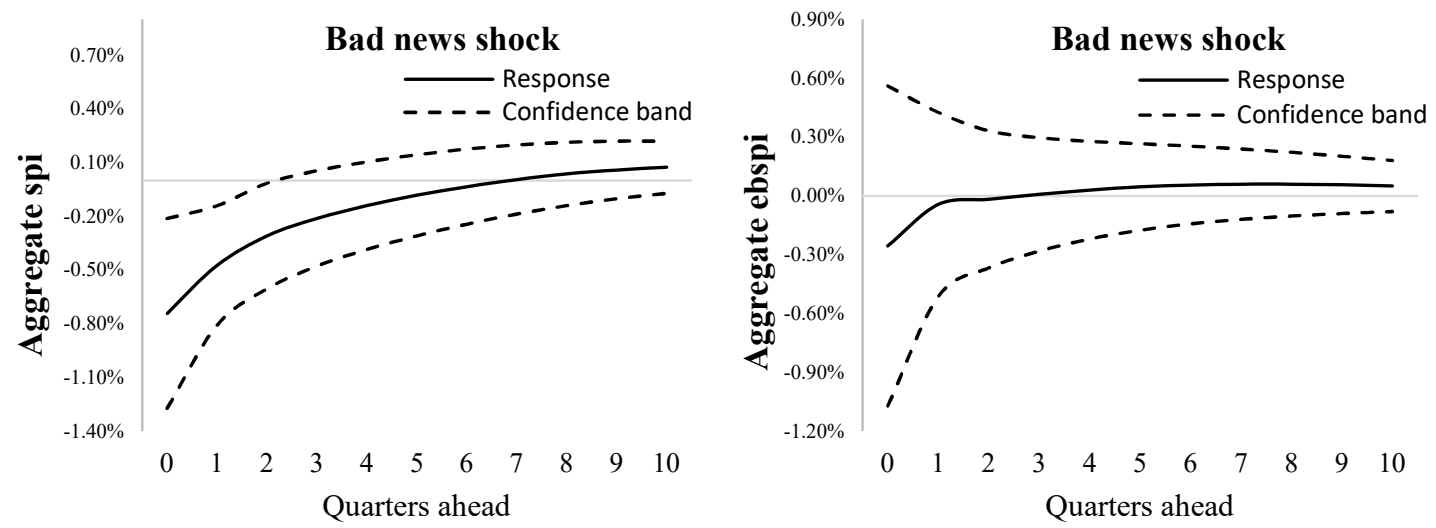

Panel C: Good News Effect
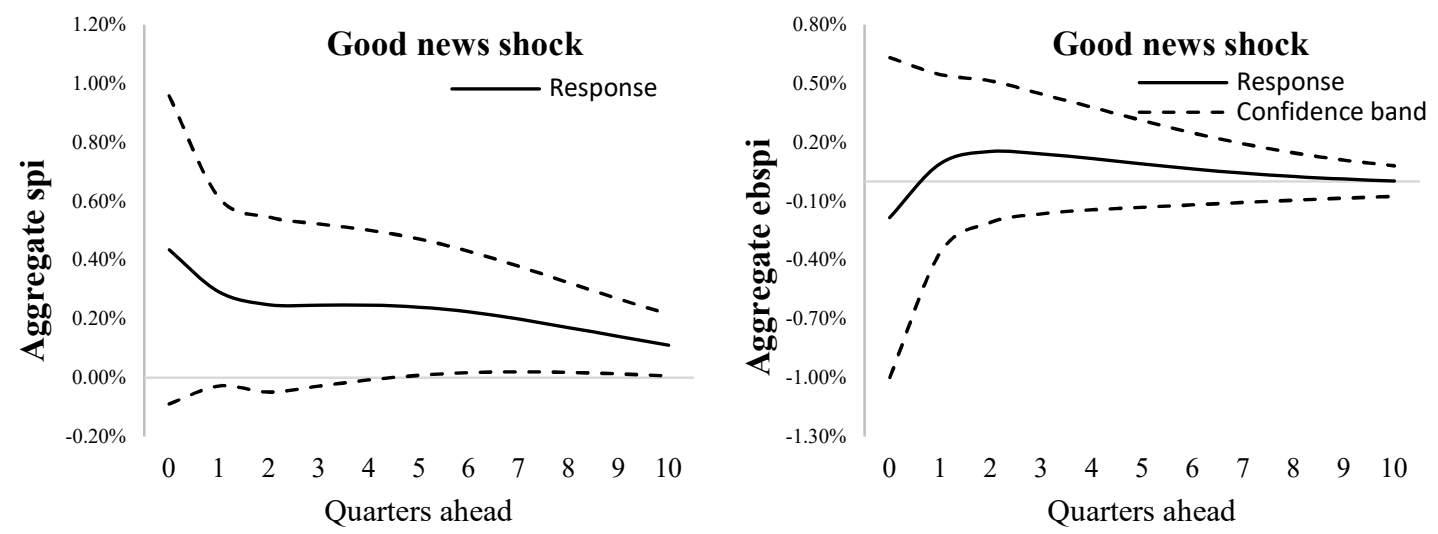

This figure shows the OIRFs' results from a VAR of macro news, inflation, unemployment, interest rate, expected real GDP growth from the SPF, aggregate earnings variables, and real GDP growth. All variables are defined in the Appendix. The confidence bands represent 90 percent confidence level. 


\section{Figure 7}

Vector Autoregression Analysis: Aggregate Earnings Variables and Other Macroeconomic Indicators

$Y_{q+1}=\alpha+\beta Y_{q}+\varepsilon_{q+1}$ where $Y_{q}=\left(\right.$ inf $_{q}(p p i)$, unem $_{q}$, int $_{q}, E_{q}\left(r g d p_{q+1}\right)$, spi $_{q}$, ebspi $_{q}$, rgdp $_{q}$, consump $_{q}$, dispincome $_{\boldsymbol{q}}$, invest $\left._{\boldsymbol{q}}\right)$

\section{Panel A: Aggregate Special Items Effect}
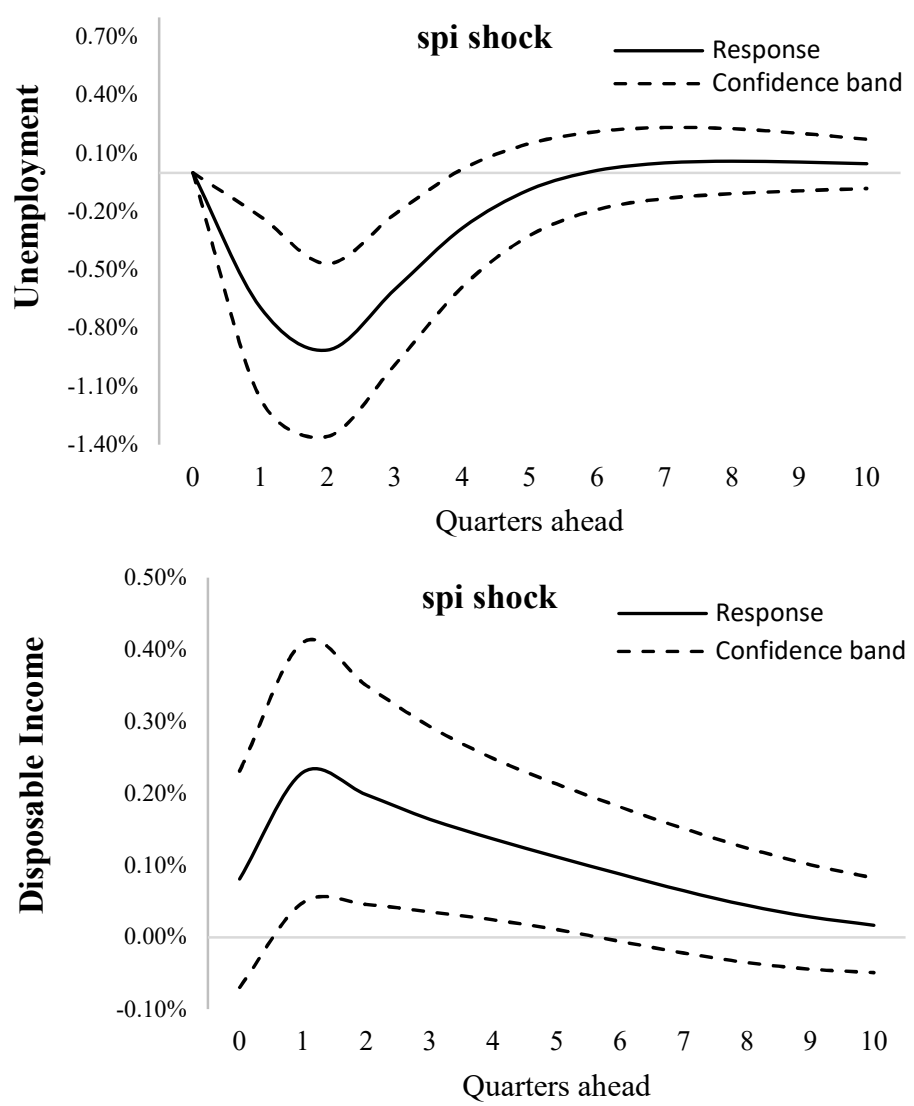
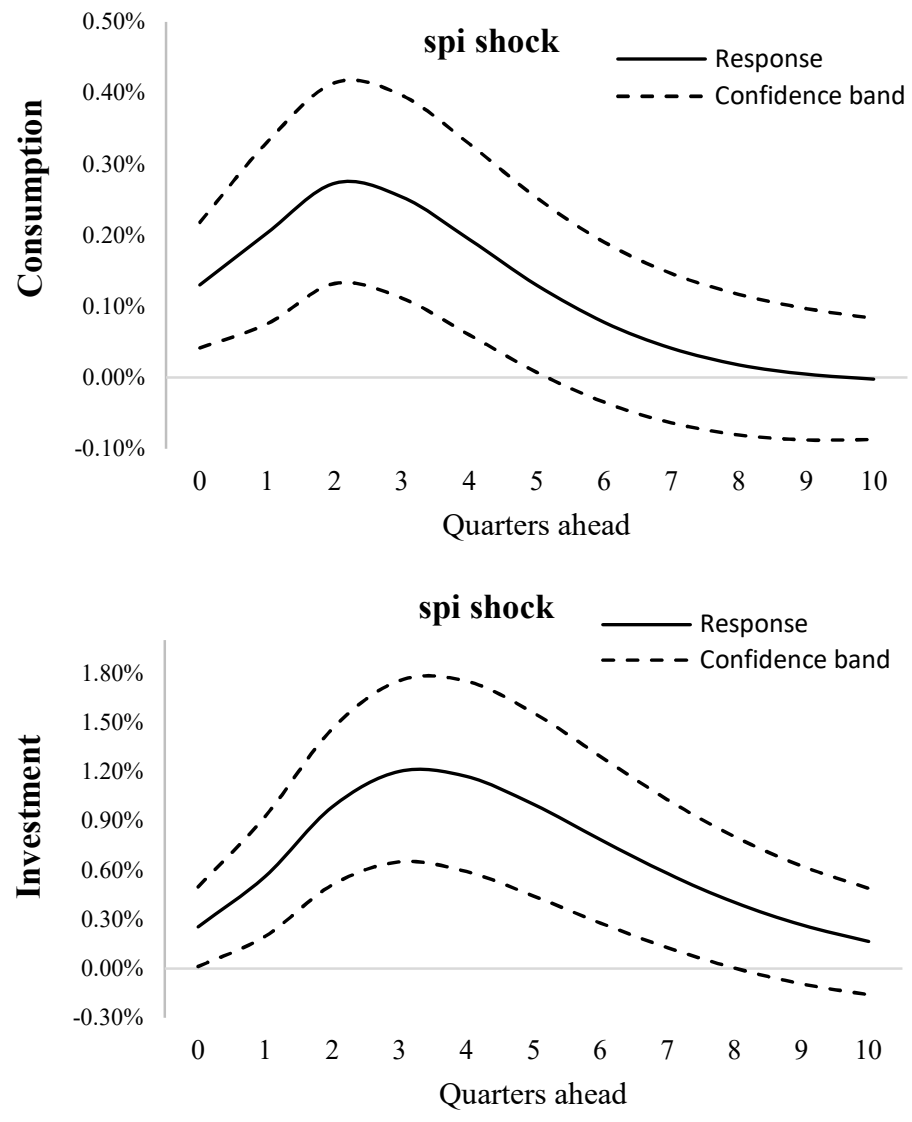


\section{Figure 7 (Continued)}

Vector Autoregression Analysis: Aggregate Earnings Variables and Other Macroeconomic Indicators

$Y_{q+1}=\alpha+\beta Y_{q}+\varepsilon_{q+1}$ where $Y_{q}=\left(\right.$ inf $_{q}(p p i)$, unem $_{q}$, int $_{q}, E_{q}\left(r g d p_{q+1}\right)$, spi $_{q}$, ebspi $_{q}$, rgdp $_{q}$, consump $_{q}$, dispincome $_{q}$, invest $\left._{q}\right)$

Panel B: Aggregate Earnings Before Special Items Effect
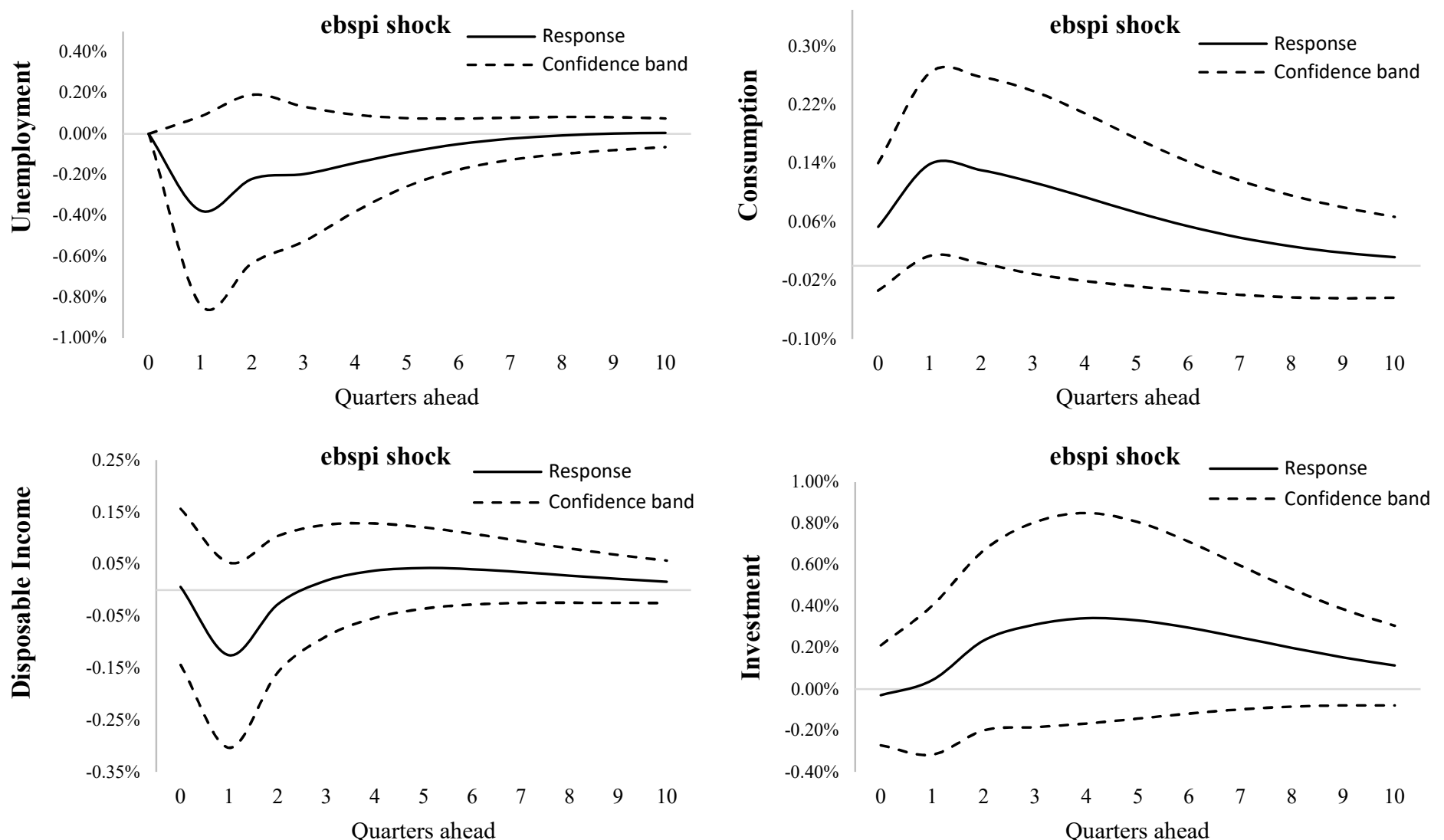

This figure shows the OIRFs' results from a VAR of inflation, unemployment, interest rate, expected real GDP growth from the SPF, aggregate earnings variables, real GDP growth, consumption, disposable income, and investment. All variables are defined in the Appendix. The confidence bands represent 90 percent confidence level. 